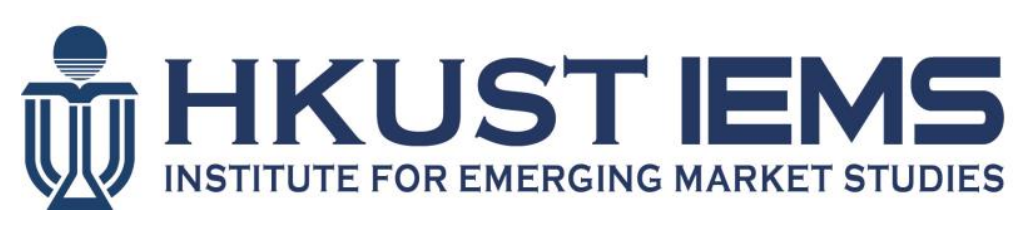

\title{
Financing Small and Medium Enterprises in China: Recent Trends and Prospects beyond Shadow Banking
}

\author{
Kellee S. Tsai
}

HKUST IEMS Working Paper No. 2015-24

May 2015

\begin{abstract}
HKUST IEMS working papers are distributed for discussion and comment purposes. The views expressed in these papers are those of the authors and do not necessarily represent the views of HKUST IEMS.
\end{abstract}

More HKUST IEMS working papers are available at: http://iems.ust.hk/WP 


\title{
Financing Small and Medium Enterprises in China: Recent Trends and Prospects beyond Shadow Banking
}

Kellee S. Tsai

HKUST IEMS Working Paper No. 2015-24

May 2015

\begin{abstract}
Small and medium enterprises (SMEs) represent the backbone of China's economy, yet they lack access to bank credit. SMEs thus rely on a wide range of alternative sources, including informal finance, online peer-to-peer (P2P) platforms, registered non-banking financial institutions (NBFIs), and underground financiers. This paper distinguishes among different types of 'shadow banking' to clarify popular misconceptions about the nature of risks associated with informal financial intermediation in China. The evolution of SME finance in other contexts suggests that regulated and well-managed NBFCs provide an enduring foundation for commercialised financial intermediation even in advanced industrialised economies.
\end{abstract}

\section{Author's contact information}

Kellee S. Tsai

Division of Social Science

HKUST Institute for Emerging Market Studies

The Hong Kong University of Science and Technology

Clear Water Bay, Kowloon

Hong Kong

T: +852 63907782

E: ktsai@ust.hk 


\title{
Financing Small and Medium Enterprises in China: Recent Trends and Prospects beyond Shadow Banking
}

\author{
Kellee S. Tsai \\ Head and Professor, \\ Hong Kong University of Science \& Technology, ktsai@ust.hk \\ Professor (on leave, 2013-2016) \\ Johns Hopkins University, ktsai@jhu.edu
}

\section{Primary Contact:}

ktsai@ust.hk

Division of Social Science

Hong Kong University of Science \& Technology

Clear Water Bay, Kowloon

Hong Kong SAR

Tel: 85263907782

\section{Acknowledgements:}

The author gratefully acknowledges the cooperation of Eric Slighton of Aktis Capital for access to relevant data; and research assistance by Tina Zhou, Sherry Qiao, and Warren Lu. 


\title{
Financing Small and Medium Enterprises in China: Recent Trends and Prospects beyond Shadow Banking
}

\author{
Small and medium enterprises (SMEs) represent the backbone of China's \\ economy, yet they lack access to bank credit. SMEs thus rely on a wide range \\ of alternative sources, including informal finance, online peer-to-peer (P2P) \\ platforms, registered non-banking financial institutions (NBFIs), and \\ underground financiers. This paper distinguishes among different types of \\ 'shadow banking' to clarify popular misconceptions about the nature of risks \\ associated with informal financial intermediation in China. The evolution of \\ SME finance in other contexts suggests that regulated and well-managed \\ NBFCs provide an enduring foundation for commercialised financial \\ intermediation even in advanced industrialised economies.
}

\footnotetext{
'Private firms have become the main source of economic growth, the sole source of increasing employment, and the major contributor to China's growing and now large role as a global trader.'

- Nicholas Lardy, Peterson Institute for International Economics, 14 October 2014
}

\begin{abstract}
'There is a mismatch between China's real economy and the financial system. The country's real economy is largely comprised of farmers, small and medium-sized businesses, and yet the financial sector is dominated by big banks that prefer to deal with big companies.'
\end{abstract}

- Justin Yifu Lin, Peking University, 28 August 2014

\begin{abstract}
'The Asian financial crisis provides ample evidence of the risks associated with the absence of a balanced financial sector with multiple channels of financial intermediation. NBFIs play an important role in a balanced and diversified financial sector that is relatively robust and stable.'
\end{abstract}

- The World Bank, 2002

In recent years, alarmist headlines about the rise of shadow banking in China have obscured fundamental structural realities about the relationship between the country's economic growth and financial development. According to the National Bureau of Statistics, small and medium enterprises (SMEs) account for over 97 per cent of registered industrial firms in China $[A D B, 2013] .{ }^{1}$ They 
also employ nearly 65 per cent of the workforce and generate 60 per cent of China's GDP. Yet larger state-owned enterprises (SOEs) receive over 75 per cent of loans extended by state-owned commercial banks [Netease Finance, 2014], and account for over 60 per cent of publicly listed businesses on China's stock markets [Zhongguowang, 2012]. Given such financing constraints, it is not surprising that SMEs rely on a remarkable variety of non-banking financing mechanisms. These include traditional forms of informal finance, online peer-topeer (P2P) platforms, microfinance institutions, and legally registered nonbanking financial institutions (NBFIs). Popular media coverage of shadow banking misleadingly implies that all forms of non-bank finance carry substantial risk. By contrast, this paper distinguishes among different types of non-bank finance to clarify popular misconceptions about informal financial intermediation in China. Given that SME demand for financial services will continue to expand, it is important to understand the reasons for this demand; the institutions that have emerged in response; the regulatory environment for mitigating risk in the non-banking financial sector; and the potential trajectory of SME finance in China.

The paper makes three main arguments. First, the SME financing gap will persist as a systemic issue in China given that demand for SME finance is growing faster than its supply. Second, the services provided by NBFIs should not be conflated reflexively with shadow banking. Third, the evolution of SME finance in other contexts suggests that regulated and well-managed NBFIs provide an enduring foundation for commercialised financial intermediation even in advanced industrialised economies. Empirically, the paper draws on government statistics, SME surveys, and case studies of NBFIs. The findings are 
framed relative to how SME finance has developed in other East Asian and OECD countries.

The paper proceeds as follows. The first section reviews the evolution and contribution of private SMEs to China's reform-era economy. The second section summarises the reasons why SMEs continue to face challenges in accessing bank credit. The third section addresses definitional issues relating to non-banking financial intermediation, and delineates the alternative forms of financing mechanisms that SMEs have relied on. The fourth part presents examples of NBFIs that have varying levels of commercial viability and success. The final part situates China's financial development in comparative context. The historical experience of advanced industrialised economies shows that while large corporations benefited from the establishment of formal banks and securities markets, a variety of NBFIs emerged to serve the particular financing needs of SMEs. Yet the rise of non-banking financial intermediation was not merely a transitory stage in the process of economic modernisation. To date, both SMEs and NBFIs play a vital role in high-income countries, and their economic contributions are especially evident in Asia, including China.

\section{SMEs: China's Economic Engine}

SMEs have represented the backbone of China's economic growth since the commencement of economic reform in the late 1970s. The following brief historical overview of private sector development in the past three decades shows how SMEs emerged on the margins of the socialist economy, earned official legitimacy, and continue to thrive as an essential, flexible, marketoriented core of the Chinese economy. 
During the early years of the reform era, individual entrepreneurs who lacked stable wage employment in the state sector took advantage of the loosening policy environment to engage in petty commerce and trading. Private restaurants, retail stores, and rural household factories sprung up swiftly in reaction to gaps left by the socialist economy [Solinger, 1984]. Although it was illegal to run private enterprises with more than eight workers until 1988, China's entrepreneurs nonetheless devised creative ways to disguise growing manufacturing operations by falsely registering them as 'collective enterprises,' which did not face any numerical limits on employees. ${ }^{2}$ Such businesses were called 'red hat enterprises' because they wore a politically acceptable registration status. The official ideological slogan of building 'market socialism with Chinese characteristics' left room for such practices, which stretched the boundaries of the planned economy into increasingly unplanned sectors.

Ultimately, China's private entrepreneurs not only stretched, but also redefined the legal boundaries for profit-oriented activities [Tsai, 2007]. As the ideological climate for private businesses relaxed in the 1990s, private traders, retailers, manufacturers, and even financiers flourished-often in quiet partnership with local government officials. By the late 1990s, nearly one-third of Chinese Communist Party (CCP) members, 'red capitalists,' were engaged in some form of private enterprise. In recognition of this politically awkward reality, then President Jiang Zemin revised the CCP constitution in 2001 to allow capitalist membership in the Party. Rather than marginalizing private entrepreneurs, the Party made the strategic decision to incorporate and legitimise commercial profit [Dickson, 2003]. 
Official legitimation of red capitalists removed a major political barrier to larger-scale private enterprises. Nonetheless, SMEs continued to account for the overwhelming majority of China's registered businesses throughout the 2000s. SME growth persisted even during the $\mathrm{Hu}$ Jintao administration that advanced the official slogan of 'promoting the public sector, diminishing the private sector' (guojin mintui). Large SOEs benefited from the policy environment of the mid2000s. Yet the development of SMEs not only kept up, but surpassed the state sector in macroeconomic relevance to the Chinese economy. The following graphs show that despite occasional dips in growth rates, the general arc of private sector growth, absorption of national employment, and contribution to industrial output has been robust.

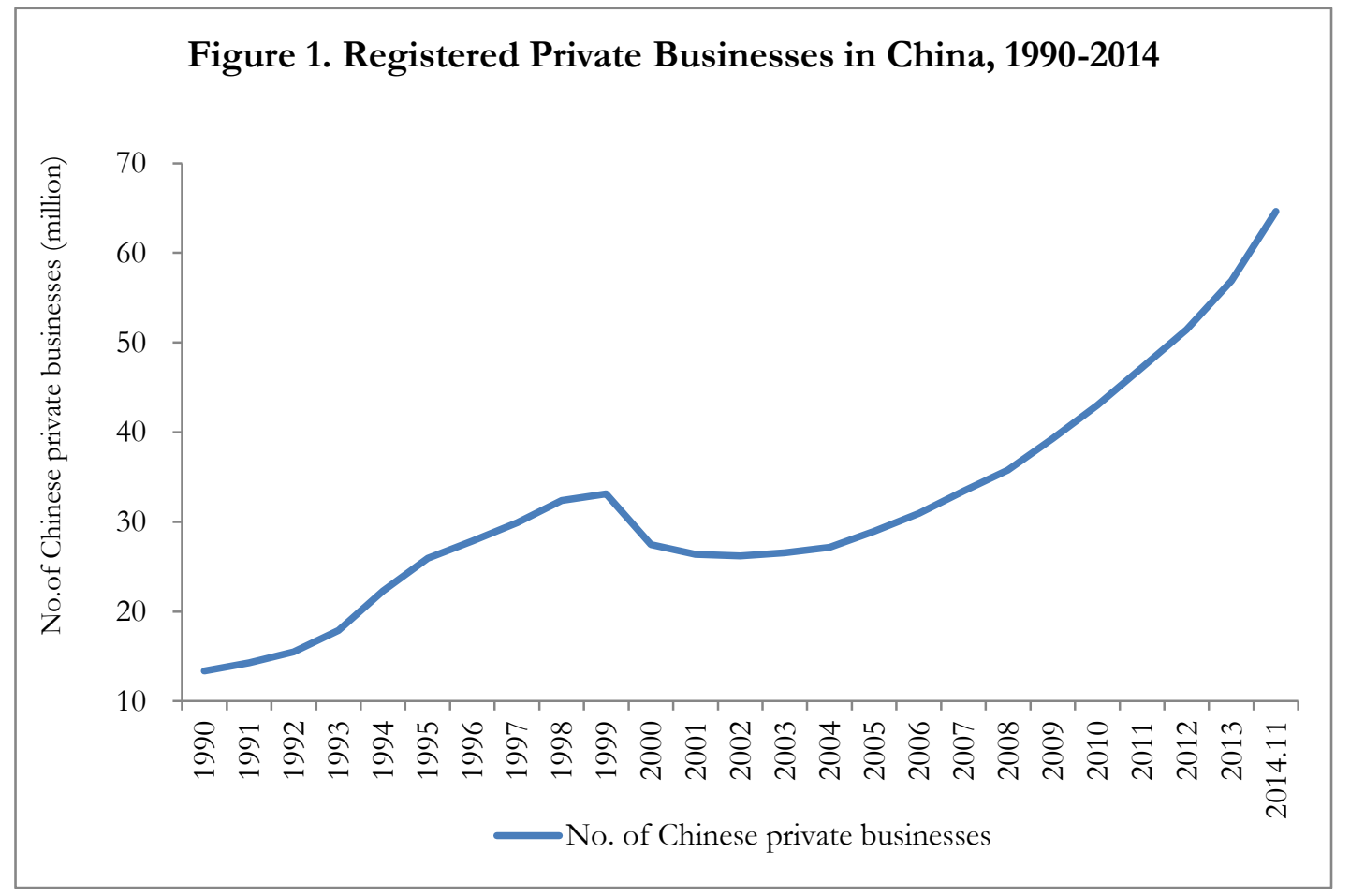

Source: State Administration for Commerce and Industry. 


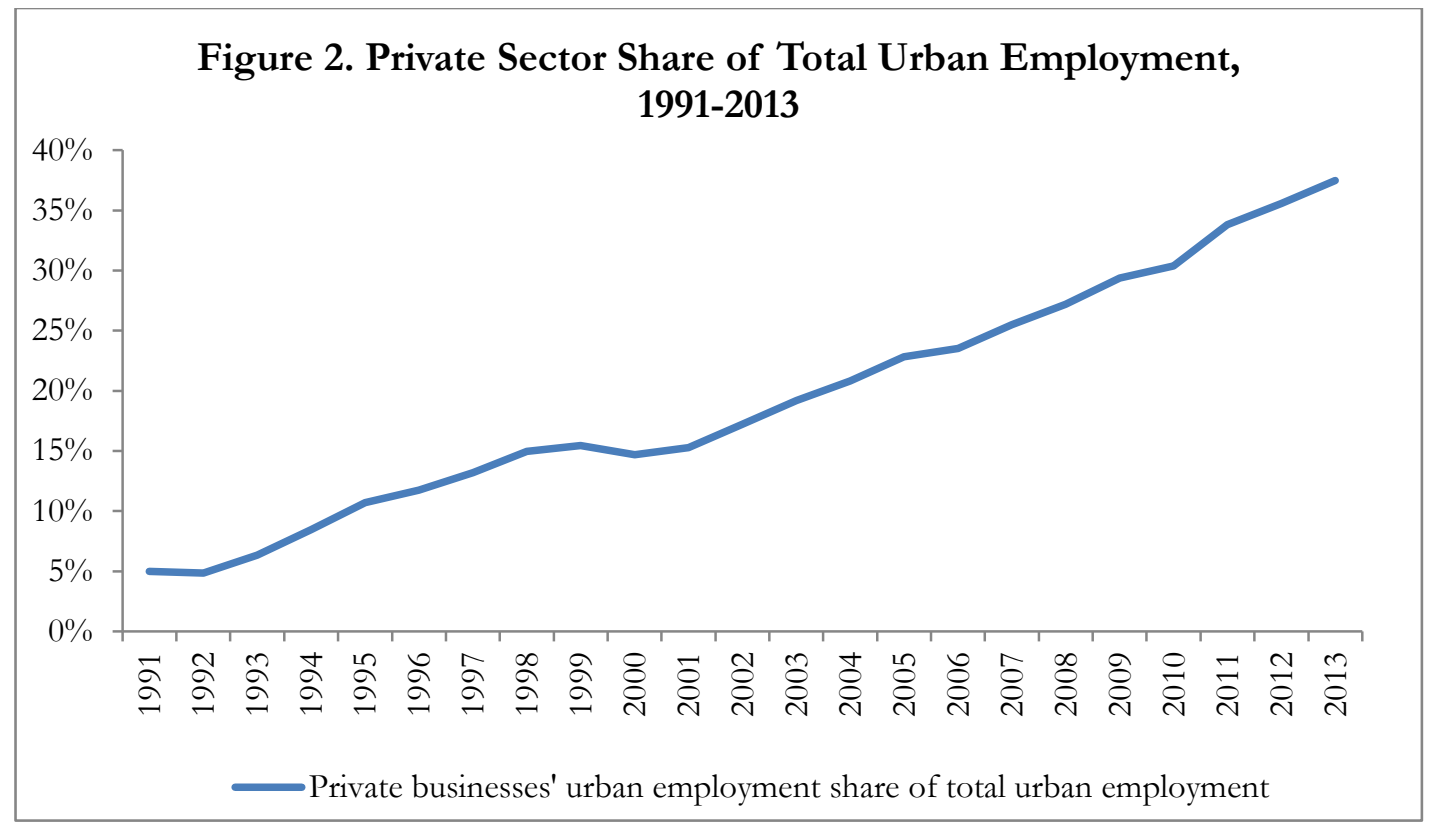

Source: National Bureau of Statistics, China Statistical Yearbook, various years.

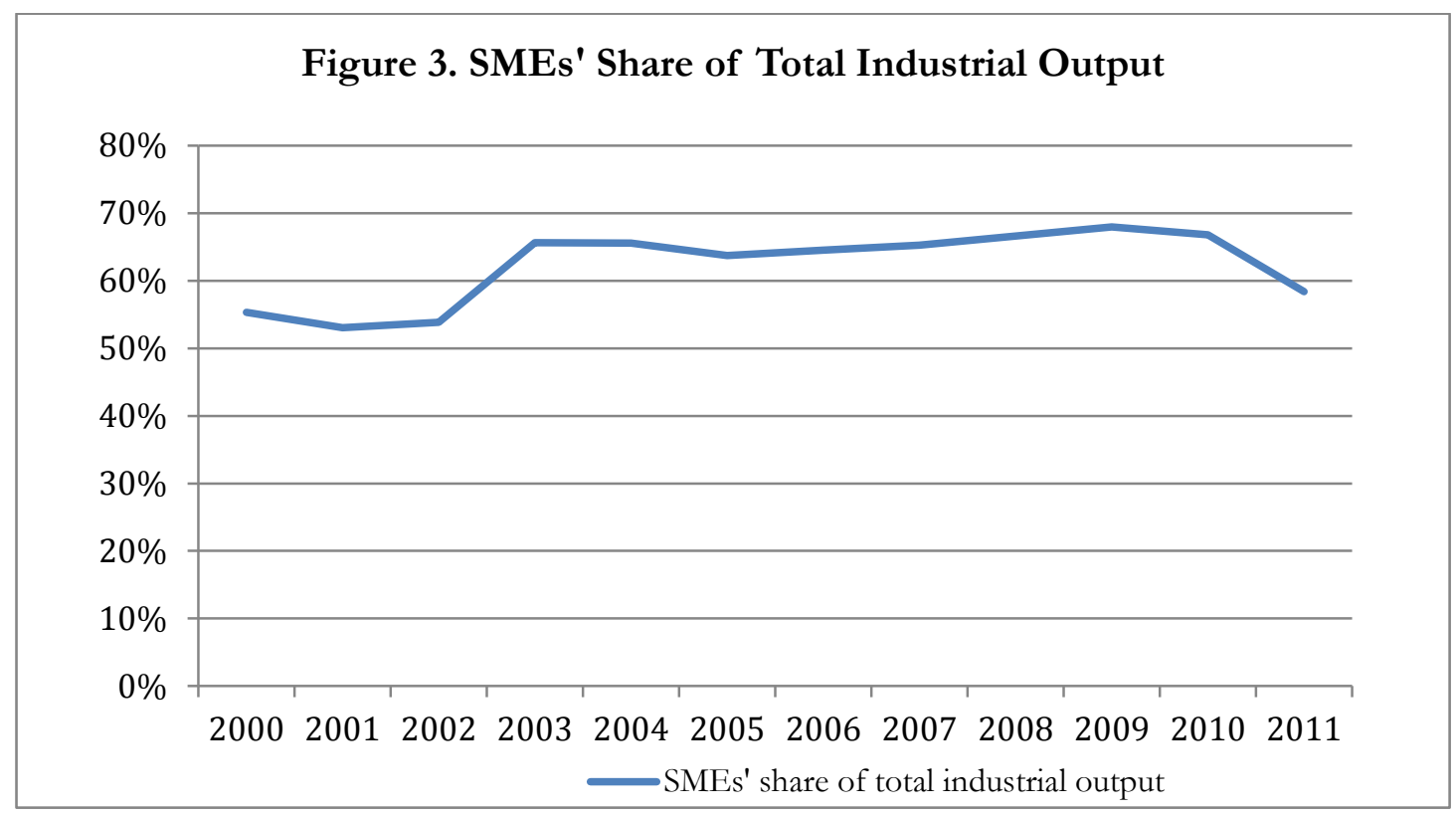

Source: National Bureau of Statistics, China Statistical Yearbook, various years.

In addition to steady growth in business registrations, share of urban employment, and contribution to China's industrial output, private firms have also outperformed the state sector in terms of return on assets (ROA). Figure 4 shows that the private sector has consistently maintained a higher ROA than state-owned industrial enterprises; and the gap in ROA has widened markedly 
since the global financial crisis. Although both private and SOEs experienced declines in ROA between 2007 and 2009, the financial performance of private businesses recovered more quickly and continued on an upward trajectory. By contrast, even with access to subsidised credit (discussed below), SOEs face continuing challenges.

Figure 4. Return on Assets of Chinese Industrial Firms by Ownership

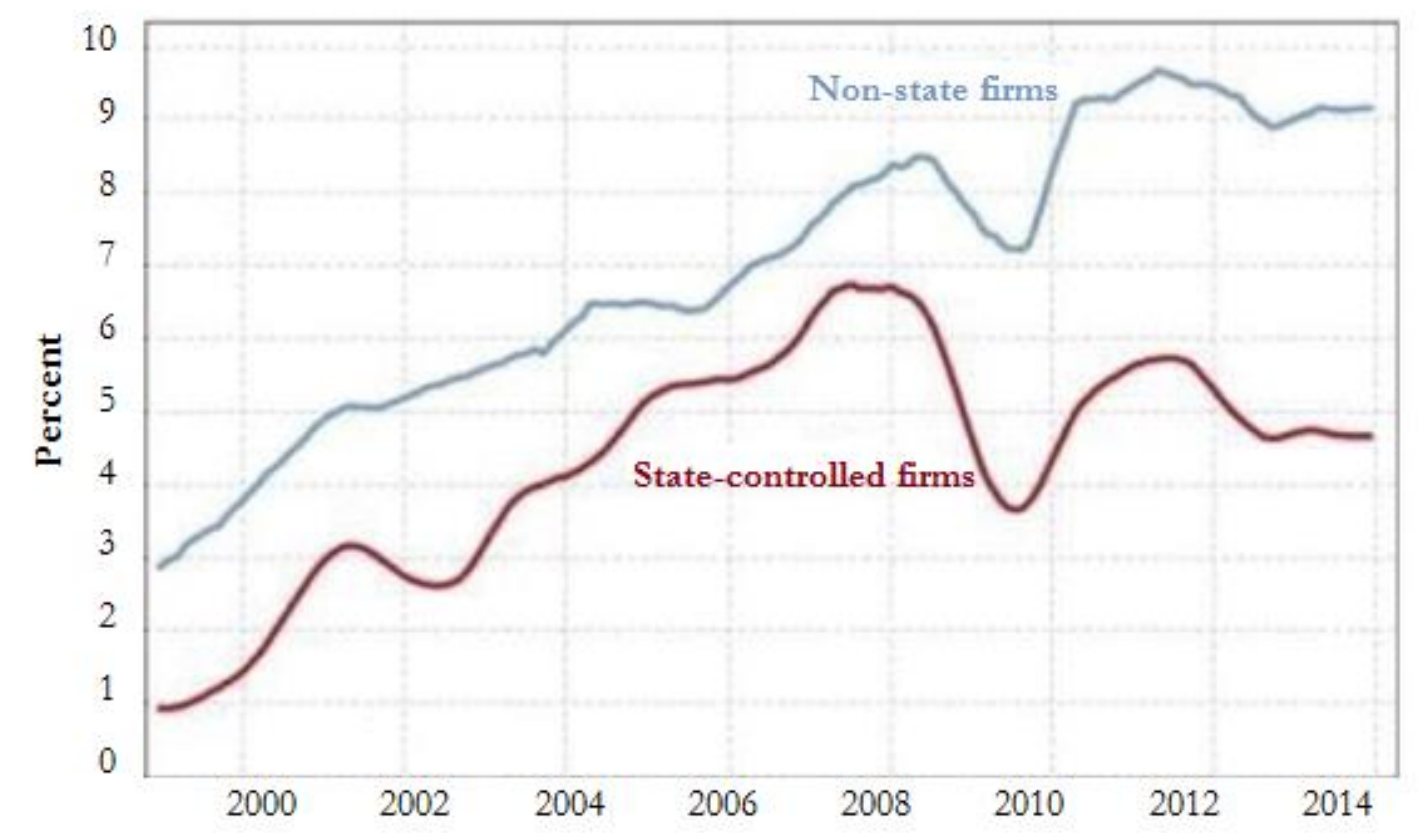

Source: China Spectator, May 2, 2014.

\section{Limits on Bank Lending to Private SMEs}

Despite their on-going contributions to China's economic development, SMEs face significant barriers in accessing credit from state-owned commercial banks. In 2013, only 23.2 per cent of bank loans were extended to SMEs [CBRC, 2014]. Access to working capital loans is even more restricted: only 4.7 per cent of short-term loans went to SMEs. Indeed, one of the enduring paradoxes of China's reform-era growth is its maintenance of a bank-dominated financial system that privileges lending to state-owned enterprises (SOEs) rather than the 
thriving private sector. There are five main reasons why the most productive, market-oriented sector of China's economy is marginalised by the state banking system. ${ }^{3}$

The first is rooted in political concerns about supporting the state sector and maintaining social stability. State banks have been pressured by local governments to provide soft loans to SOEs as a means to avoid mass unemployment. This is one of the main reasons why state banks had accumulated such high levels of non-performing loans (NPLs) by the 1990s. Although China's 'Big 4' commercial banks were subsequently recapitalised in preparation for their IPOs in the 2000s, NPLs have grown and re-emerged as a potential concern since the stimulus-induced bank lending of the late $2000 \mathrm{~s}$ [Zhang, Tian and Li, 2012; Weinland, 2015].

The second reason that SMEs face challenges in accessing bank credit reflects the developmental priorities of central and provincial governments. State banks extend loans to enterprises in sectors that have been identified for preferential treatment as a matter of domestic industrial policy (e.g., automobiles, pharmaceuticals, computer components). This type of targeted lending is not corrupt or illegal; it is policy oriented. China's state media occasionally exhorts banks to increase their lending to SMEs, but such statements have not been backed up by official policy directives to ensure their implementation [Garaci, 2012]. Indeed, sub-branch level officers are primarily charged with attracting deposits and have limited authority over credit decisions.

Third and relatedly, on-going financial repression-meaning governmental suppression of interest rates below market levels-serves 
industrial policy at the expense of savers. Under financial repression, household savings have been transferred through the banking system to subsidise credit to SOEs, capital-intensive industry, and real estate developers [Pettis, 2013; Lardy, 1998]. Interest rate ceilings also inhibit lending to SMEs because banks are not able to price loans to reflect the trade-off between profit and risk. ${ }^{4}$ Liberalisation of interest rates would benefit bank depositors and SMEs, while stimulating domestic consumption. However, a higher cost of capital would further erode state sector profits.

The fourth reason for the private sector's exclusion from official credit relates to the limited organisational and technical capacity of state banks to serve the non-state sector. Credit officers have not been trained to evaluate loan applications according to commercial standards of creditworthiness, and until the late 1990s, they were not held accountable for high levels of SOE NPLs in their portfolios. The anti-corruption campaign launched by China's present leadership has reinforced the reluctance of state banks to lend to SMEs, which carry a higher perceived risk of payment delays, if not defaults.

The fifth reason why bank lending to private entrepreneurs represents such a small proportion of official credit is due to the ideological and political sensitivity of using party-state resources to support capitalist ventures. Especially during the first two decades of reform, loan officers were hesitant to work with private entrepreneurs due to uncertainty about the potential consequences. Even though credit officers are now officially encouraged to lend to profit-making businesses regardless of ownership type, they remain wary about making bad loans to private individuals and SMEs. If a SOE faces payment difficulties or defaults on a loan, the problem is contained within the public 
sector. However, as many bank managers have echoed in the course of field interviews, they are much more likely to be reprimanded (or simply fired) by superiors for losses incurred through loans to private businesses. In short, state banks remain institutionally biased against private sector clients.

Given these structural constraints on private sector borrowing from state banks, China's SMEs have depended on non-banking sources of credit since the earliest years of reform. ${ }^{5}$ In surveys of private businesses conducted during the mid-1990s and mid-2000s, over two-thirds of the respondents indicated that they had relied on some form of informal finance [Tsai, 2002]. More recent research indicates that reliance on non-banking financing mechanisms has not abated. A World Bank survey of 2,700 private firms in 2011 to 2013 found that only 25 per cent had bank credit and 90 per cent drew on internal financing [World Bank, 2012]. Within that period, a 2012 survey of SMEs in fifteen provinces conducted by China's Central University of Finance and Economics (CUFE) found that 57.5 per cent had participated in informal credit markets [ $\mathrm{Li}$ and $H u, 2013]$. The bi-annual national surveys private enterprises administered by the All-China Federation of Industry and Commerce [Various years since 1992] consistently find that 'accessing bank credit' is among the top self-reported challenges facing the private sector. As such, SMEs in China continue to rely heavily on non-banking financial intermediaries-and as discussed later in the paper, such credit constraints are shared by SMEs in other countries.

\section{Defining the Universe of Non-banking Financial Intermediation}

Some conceptual issues need to be addressed before outlining the various expressions of non-banking financial intermediation in China. Above all, it is 
important to emphasise that in China's regulatory context, 'informal' finance does not necessarily mean that it is illegal. Most forms of informal finance-and what is now known as shadow banking-are 'quasi-regulated' in the sense that some financial institutions may not be supervised by the Central Banking Regulatory Commission (CBRC), but are registered with local branches of other bureaucracies, such as the Industrial Commercial and Management Bureau, Ministry of Civil Affairs, or local Finance Office. (Table 1 delineates the various bureaucracies that register non-banking financial institutions.)

Table 1. Registration Status of Select Non-Banking Financial Institutions (NBFIs)

\begin{tabular}{|l|l|c|}
\hline \multicolumn{1}{|c|}{ Type of NBFI } & \multicolumn{1}{|c|}{ Registration Authority } & \multicolumn{1}{|c|}{$\begin{array}{c}\text { \# Registered } \\
\text { (year) }\end{array}$} \\
\hline $\begin{array}{l}\text { Credit guarantee } \\
\text { companies }\end{array}$ & $\begin{array}{l}\text { Provincial governments: Public Finance Office, } \\
\text { SME Bureau, local Finance Department } \\
\text { County governments: CBRC NBFI division }\end{array}$ & $8,427(2012)$ \\
\hline $\begin{array}{l}\text { Microfinance/small loan } \\
\text { companies }\end{array}$ & $\begin{array}{l}\text { Civil Affairs Office: NGOs } \\
\text { Local government: Finance Office }\end{array}$ & $8,217(2014)$ \\
\hline Pawn shops & ICMB, MOFCOM & $7,000(2014)$ \\
\hline Trust companies & $\begin{array}{l}\text { Provincial governments (>64\%) } \\
\text { Central governments (15\%) } \\
\text { Shanghai Trust Registration Center (not enforced) } \\
\text { CBRC }\end{array}$ & $6814)$ \\
\hline Leasing companies & $\begin{array}{l}\text { CBRC: domestic } \\
\text { MOFCOM: JVs, WFOEs }\end{array}$ & $26(2014)$ \\
\hline Rural mutual aid funds & $\begin{array}{l}\text { ICMB } \\
\text { Poverty Alleviation Bureau }\end{array}$ & $1,627(2015)$ \\
\hline P2P lending platforms & ICMB & $114(2014)$ \\
\hline Crowd funding platforms & ICMB & \\
\hline
\end{tabular}

CBRC: China Banking Regulatory Commission ICMB: Industrial \& Commercial Management Bureau MOFCOM: Ministry of Commerce NBFI: Non-banking financial institution

The main difference between banks and licensed NBFIs is that the latter are not permitted to accept deposits. Meanwhile, some forms of informal finance are unregulated. But to be sure, some financing practices are indeed, illegal. According to the CBRC, only banking entities with financial licenses are permitted to mobilise savings deposits from the public; and financial institutions 
are not permitted to charge interest rates more than four times the benchmark lending rate set by the PBOC. (See Appendix B for a summary of recent regulations governing various NBFIs.) However, these regulations are not well enforced outside of the formal financial sector. A vast and innovative array of informal financing mechanisms has flourished, mainly in response to unmet demand for financial services, but also in response to arbitrage opportunities due to financial repression. ${ }^{6}$ Within this realm, China's leading expert on informal finance, Professor Li Jianjun [2009] of CUFE, distinguishes among informal finance, underground finance, illegal finance, and unobserved finance based on their usage by other researchers in China. The differences may be summarised as follows:

- Informal finance comprises interpersonal borrowing, trade credit, rotating credit associations, as well as registered non-banking financial institutions, such as credit unions, pawnshops, credit guarantee companies, negotiable securities firms, insurance companies, etc.

- Underground finance includes practices and organisations that are not registered, and therefore, related financial transactions are not legally protected. The usage of this term overlaps with informal finance, and has been sub-divided further into 'grey' forms of underground finance-that facilitate economically productive or socially beneficial activities-and 'black' finance, which has detrimental effects.

- Illegal finance is limited to criminal and fraudulent financial transactions that may constitute various forms of corruption, including embezzlement of state funds.

- Unobserved finance is the broadest category, encompassing any financial activity that is not captured in national accounting and statistical information systems. The entirety of illegal finance falls into this category, as do the 'black' portions of underground and informal finance.

The diffusion of 'shadow banking' into popular discourse in the aftermath of the 2008 global financial crisis has complicated the preceding conceptual distinctions by casting a pejorative film over non-banking financial 
intermediation in general. ${ }^{7}$ The irony is that shadow banking originally referred to opaque products issued by well-established formal banks. The term 'shadow banking' gained prominence in 2007 in the context of financial institutions in the United States that engaged in 'maturity transformation' by using short term funds (e.g., deposits) to finance longer term assets (e.g., real estate) [Kodres, 2013]. More specifically, the Federal Reserve Bank of New York identifies securitised financial instruments-including asset-backed commercial paper (ABCP), asset-backed securities (ABS), collateralised debt obligations (CDOs) and repurchase agreements (repos)—as shadow banking [Pozar, Adrian, Ashcraft and Boesky, 2010].

But the Financial Stability Board (FSB) [2013] later defined shadow banking more broadly as 'the system of credit intermediation that involves entities and activities fully or partially outside the regular banking system, or non-bank credit intermediation in short.'8 Based on this expansive definition, the International Monetary Fund [2014] observes that in emerging market economies, growth in shadow banking is outpacing that of the regular banking sector; and shadow banking assets as a percentage of GDP in emerging markets grew from 6 to 35 percent during 2002 to 2012. Globally, the scale of shadow banking assets exceeds global GDP, and is regarded as a particular risk for the US where shadow banking assets exceed the value of assets in traditional banks. The most reliable estimates of the scale of shadow banking in China was 25 trillion yuan in 2012 and 32.7 trillion yuan in 2013[Wang and Li, 2013; Shi, 2014]. To put things in comparative perspective, this represented 48 per cent and 57 per cent of China's GDP in those years, respectively. By contrast, in the US the value of shadow banking exceeds GDP by over three times. 
The FSB's encompassing definition of shadow banking may help regulators identify sectors in need of greater prudential oversight. Given the term's negative connotation, however, lumping all forms of non-banking financial intermediation into 'shadow banking' offers limited analytic value for understanding the types of activities that carry systemic risk versus those that are established features of a healthy financial system serving diversified markets. Rather than mince the precise boundaries of formal vs. informal and legal vs. illegal finance, Table 2 presents the forms of non-banking financial intermediation used by SMEs in China according to their degree of institutionalisation. The latter can be assessed based on the extent to which they entail documented rules and procedures, the stability of their physical or virtual operating space, and whether they are legitimately registered and regulated with a government entity. ${ }^{9}$

Table 2. Forms of Non-Banking Financial Intermediation

\begin{tabular}{|c|c|c|}
\hline Least Institutionalised & Semi-Institutionalised & Institutionalised \\
\hline $\begin{array}{l}\text { - Interest-free } \\
\text { uncollateralised } \\
\text { lending among } \\
\text { friends, family, \& } \\
\text { businesses } \\
\text { - } \begin{array}{l}\text { Trade credit } \\
\text { among businesses }\end{array} \\
\text { - Underground } \\
\text { money lenders } \\
\text { (with high } \\
\text { interest) }\end{array}$ & $\begin{array}{l}\text { - } \begin{array}{l}\text { Rotating savings } \\
\text { and credit } \\
\text { associations }\end{array} \\
\begin{array}{l}\text { Non- } \\
\text { governmental } \\
\text { investment } \\
\text { alliances }\end{array} \\
\text { - } \begin{array}{l}\text { Reciprocal loan } \\
\text { guarantee } \\
\text { networks }\end{array} \\
\begin{array}{l}\text { Internet Finance } \\
\text { (since 2007) }\end{array} \\
\text { Crowd funding } \\
\text { P2P platforms }\end{array}$ & $\begin{array}{l}\text { - Microfinance/small } \\
\text { loan companies* } \\
\text { - Leasing companies } \\
\text { - Credit guarantee } \\
\text { companies } \\
\text { - Pawnshops } \\
\text { - Trust \& investment } \\
\text { companies } \\
\text { - Mutual aid societies } \\
\text { *Note that in English, '小额信贷公 } \\
\text { 司' (xiaoe xindai gongsi) refers to } \\
\text { microfinance, microcredit, and } \\
\text { small loan companies. Some } \\
\text { institutions that call themselves } \\
\text { 'microfinance companies,' } \\
\text { however, provide larger loans to }\end{array}$ \\
\hline
\end{tabular}




\begin{tabular}{|l|l|l|}
\hline & $\begin{array}{l}\text { SMEs. Entities that refer to } \\
\text { themselves as 'small loan } \\
\text { companies (SLCs),' generally focus } \\
\text { on SMEs rather than micro } \\
\text { entrepreneurs. Depending on the } \\
\text { nature of the license, some SLCs } \\
\text { face caps on loan size, but others } \\
\text { do not face such restrictions. }\end{array}$ \\
\hline
\end{tabular}

Casual, interest-free, uncollateralised borrowing from family, friends, and business associates are ad hoc and lie at the un-institutionalised end of the spectrum. Legitimately registered non-banking financial institutions (NBFIs) with modern corporate governance, accounting, information management, and creditscreening systems, lie at the other. 'Semi-institutionalised' practices include rotating credit and savings associations, which are unregistered but operate according to written contracts. Similarly, non-governmental investment alliances are documented by written agreements between private entrepreneurs in the same industry who pool funds to make larger investments in member enterprises than would otherwise be feasible. Various types of internet finance, such as crowd funding sites (e.g., DemoHour, DeamMore) and P2P lending platforms (e.g., Ppdai.com, Renrendai.com, Dianrong.com) also fall into the semiinstitutionalised category because they broker funds through parameters that are documented on-line, but are unregulated and not necessarily legitimately registered. Internet finance lies in uncharted regulatory waters. Because the online platforms put private savings at risk, essentially substituting for bank deposits, it is likely to attract CBRC regulation in the near future. ${ }^{10}$ Over 1,000 P2P sites have already ceased operating since 2011[Weinland, 2014]. Figure 5 shows the various forms of non-banking financial intermediaries according to their degree of institutionalisation and regulation. 
Figure 5. Non-Banking Financial Intermediation in China: Institutionalisation vs. Regulation

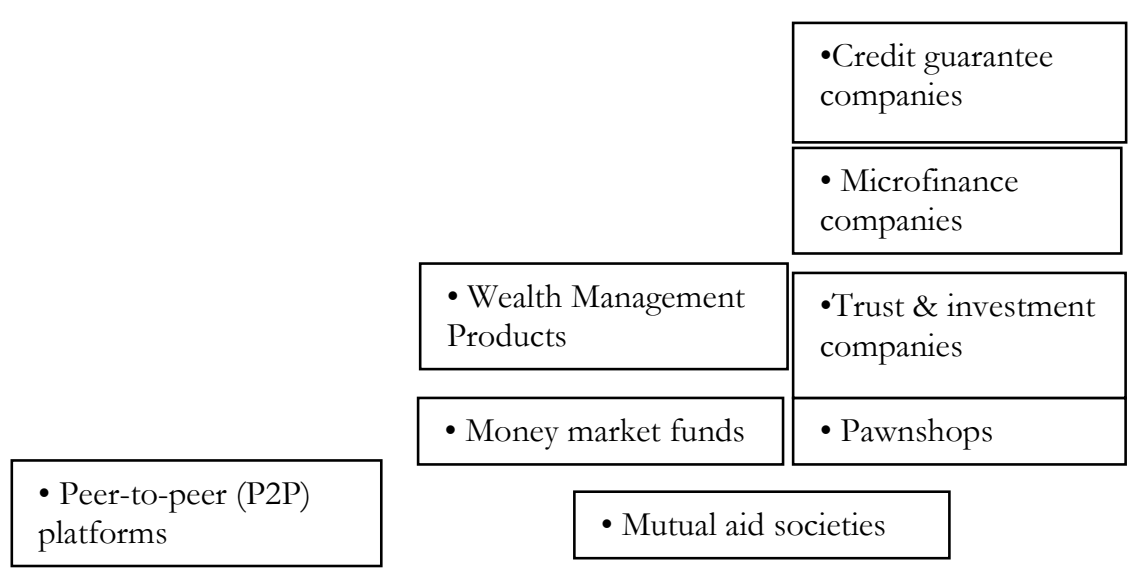

- Crowd funding

- Rotating savings and credit associations

- Non-government investment alliances

- Reciprocal loan guarantee networks

- Trade credit among businesses

- Underground banks \& money lenders (with high interest)
- Interest-free uncollateralized lending among friends, family, \& businesses

Illegal

Unregulated

Regulated 
The above typology focuses on the types of non-banking financial intermediation used by SMEs in China rather than the entire universe of what is now associated with shadow banking. In 2014, the PRC State Council [2014] identified the following three categories of shadow banking from a regulatory perspective:

1) Unlicensed and unregulated financial operators (e.g., underground banks, internet finance, P2P lending)

2) Entities operating without a finance license and inadequate supervision by credit agencies (e.g., pawnshops, credit guarantee companies, microfinance companies)

3) Inadequately supervised activities of licensed financial institutions (e.g., money market funds, wealth management products, asset securitisation).

The State Council's definition represents a reversal of the CBRC's statement, just two years earlier, that non-banking financial institutions (such as trust companies, finance companies, and off-balance sheet transactions of banks) did not constitute shadow banking [Gao and Wang, 2014]. This reversal may be attributed to the unexpectedly rapid growth of two forms of shadow banking, inspiring anxiety on the part of regulators and industry observers: local government financing vehicles (LGFVs) and wealth management products (WMPs).

Since 2008, over 10,000 loosely regulated LGFVs have been established by local governments. LGFVs broker off balance sheet loans between state banks and local governments who offer revenues from land sales and real estate as collateral. LGFVs have become the primary channel through which sub-national governments have financed public goods and large-scale infrastructure projects. Following an emergency national audit of local public finance, the National Audit Office [2013] estimates that by mid-2013 local government debt had reached 
17.9 trillion yuan (\$2.9 trillion), an increase of 60 per cent since the end of 2010 . Various analysts observe that LGFVs pose systemic risk due to their reliance on new debt to finance longer-term investment [Nomura, 2013]. The IMF estimates that local government debt reached 36 per cent of GDP in 2013 [Wei and Davis, 2015].11

Meanwhile, in partnership with banks, trust companies have been offering WMPs that advertise higher returns than the 3.3 per cent deposit rates in regular savings accounts [Zhang, 2014]. There is ambiguity in how WMPs generate 'expected returns,' given that WMPs pool funds invested in trusts, bonds equities, and money market instruments. Investments made by trusts are particularly sensitive to industrial conditions because short-term WMP returns (typically distributed every three months) may be linked with capital-intensive ventures with longer-term payoffs. In 2014, near defaults of large WMPs issued by trust companies associated with China's largest state banks drew attention to the systemic risk posed by the rapid accumulation of assets held by trusts in recent years. ${ }^{12}$ Unlike banks, which are required to set aside 20 per cent of deposits to protect savers against loan defaults, trusts are not subject to a reserve requirement.

Bank WMPs generally fall into two categories: 1) traditional bank business that is moved off balance sheet to evade reserve requirements and sector-specific lending quotas; and 2) speculative investment products that channel funds into projects that banks would not ordinarily support (primarily real estate). Both types entail maturity mismatch, but the second holds greater potential for triggering a crisis when redemption is below par and either investors lose money or the banks are forced to absorb the losses. 
The nature of risk posed by the proliferation of LGFVs and WMPs should be distinguished from that associated with the types of non-banking financial institutions that provide credit to private businesses. Rather than focusing exclusively on the current state of regulation, assessing the exposure of banks to different types of credit intermediation provides a better metric for analyzing the risk posed to financial stability. A recent research report on shadow banking in China identifies three layers of shadow banking based on such criteria: the bank off-balance sheet financing layer, the credit enhancement layer, and the non-bank lending layer [Sheng, Edelmann, Sheng and Hu, 2015].

In the top bank off-balance sheet financing layer, banks evade regulatory restrictions on capital requirements and loan-to-debt ratios by extending credit through off-balance sheet 'channeling.' The off balance-sheet supply of WMPs through trusts is the most prominent example of this top layer of shadow banking. The main source of risk stems from the mismatch between asset risk and investor appetite for risk, meaning that consumers may not be fully cognizant of the risk associated with securitised assets implicitly promising returns substantially above the bank deposit rates.

In the second credit enhancement layer of shadow banking, non-banking financial companies extend loans to businesses that are unable to access bank credit, or enable lower-credit borrowers to access larger loans from banks by providing guarantees. There is potential risk to banks because such institutions serve borrowers that unassisted, might not meet the credit standards of banks. For example, when one business faces debt service challenges in a reciprocal loan guarantee network, all the other bank loans guaranteed by that business, either directly or indirectly, are also at risk. 
The third non-banking lending layer is the most distant from the banking system itself. Pawnshops, leasing companies, P2P platforms, and microfinance companies serve private businesses in a variety of sectors. These types of nonbanking financial intermediaries face risk themselves, but pose limited systemic risk to the banking system. Credit failures are generally contained to the immediate operators and clients of such intermediaries. Moreover, non-deposit taking NBFIs do not create the same implicit obligation on the government to cover investment losses. Since they are not regulated by the CBRC, such NBFIs are not subject to the 20 per cent limit on foreign ownership of companies in China.

The triple-tiered framework for assessing the degree of systemic risk associated with shadow banking is helpful for differentiating the original type of shadow banking (the top bank off-balance sheet layer that involves maturity transformation through asset pooling and securitisation), from the more traditional forms of informal finance that have emerged in response to SME demand for credit (the credit enhancement and non-banking lending layers). Within the second and third layers of shadow banking, additional distinctions can be made in terms of risk assessment. The State Council's regulatory-based definition of shadow banking provides a starting point, along with the intermediary's degree of institutionalisation. In other words, returning to Figure 4, the entities towards the upper right quadrant of the graph have a more secure registration status, regulatory standing, and level of institutionalisation. Those include a variety of NBFIs, such as microfinance, credit guarantee, and leasing companies. Further differentiation among registered, regulated, and well- 
institutionalised NBFIs requires firm-level analysis of corporate governance, management, internal systems, and so on.

\section{Examples of Chinese NBFIs}

For illustrative purposes, this section presents three examples of NBFIs that are registered and hold operating licenses, but vary in their management, scope of business, and performance. The first company, Zouli Kechuang Microfinance Company ('ZKMFC'), went public in Hong Kong in January 2015 after operating for only four years. The second, Credit Orienwise, developed an impressive market share in China's credit guarantee industry and attracted global venture capital; but was subsequently derailed by accusations of financial malfeasance. The third example, Gangyu Guaranty, is embedded within a broader network of NBFIs that provides different types of financial services for SMEs.

\section{Zouli Kechuang Micro-finance Company}

Zouli Kechuang Micro-finance Company ('ZKMFC') was established in 2011 in Deqing county in the southern coastal province of Zhejiang, and was listed on the Hong Kong Stock Exchange in 2014 (06866:HK). Relative to China's other provinces, Zhejiang is known for having a particularly innovative range of informal financial intermediaries that serve the province's thriving, but creditconstrained private sector. ${ }^{13}$ Since the central government granted legal status to microfinance companies (MFCs) in 2008, over 8,590 licensed MFCs have been established [Wang, 2015], of which 314 are based in Zhejiang. The provincialwide MFC industry is fragmented, with the top five MFCs accounting for only 6.1 per cent of the provincial market share in mid-2014 [ZKMFC Global Offering Prospectus, 2014]. Within Deqing county, however, there are five MFCs, with 
ZKMFC accounting for 44 per cent of the total loan balance of MFCs in Deqing [ZKMFC Global Offering Prospectus, 2015]. With registered capital of 880 million yuan (US\$141 million), ZKMFC was the largest MFC in Zhejiang in 2014. ZKMFC was initially established in August 2011 as a pilot MFC. Its initial registered capital of 200 million yuan (US\$32 million) was contributed in cash by Puhua Energy (a subsidiary of Zuoli Holdings), seven corporate shareholders, and 15 individual shareholders. In accordance with MFC registration requirements, none of the corporate or individual shareholders hold more than five per cent of equity interest; and loans cannot be extended to its shareholders. ZKMFC lends primarily to SMEs, microenterprises, and individual entrepreneurs in agricultural and rural industrial activities based in Deqing, though it has applied for a license to expand into Hangzhou and Jiaxing, larger cities in Zhejiang province. ${ }^{14}$ As of 2014, ZKMFC had served over 1,200 clients with shortterm financing. Their loans range from 10,000 yuan (US\$1,600) to 25 million yuan (US\$4 million) with a term length of two months to one year. ZKMFC manages credit risk by maintaining three tiers of loan assessment and approval depending on loan size, and conducting post-loan grant reviews of its borrowers. According to its IPO prospectus, on June 30, 2014, only 0.1 per cent of ZKMFC's loan portfolio was overdue and its six-month profit margin was 64.6 per cent. Initial investor confidence in ZKMFC was reflected during its initial weeks of trading. ${ }^{15}$

Credit Orienwise Group

In 1999, Zhang Kaiyong founded the first credit guarantee company (CGC) in Shenzhen, one of China's original special economic zones adjacent to Hong Kong. Initially, the CGCs owned by Credit Orienwise Group (COG) focused on 
guaranteeing loans from state banks extended to SMEs based in Shenzhen.

Within a few years, COG had expanded to a dozen cities beyond Shenzhen, becoming one of the largest CGCs in the country [Epstein, 2009]. COG was hailed by the Forum on Inclusive Finance as China's 'first comprehensive nongovernmental corporation in the business of guarantees, investment and consulting [Situ, 2011].' By 2003, Zhang Kaiyong made it on to the Forbes list of the 400 wealthiest Chinese. Morgan Stanley backed a $\$ 100$ million bond issuance on the Singapore Stock Exchange in 2005, and shortly thereafter, COG attracted over $\$ 100$ million in private equity investment by the Carlyle Group, Citigroup Venture Capital International, General Electric Capital, and the Asian Development Bank (ADB). At its peak, COG guaranteed $\$ 2$ billion worth of loans and engaged in \$250 million of indirect lending [Epstein, 2009].

However, in August of 2008, COG started to unravel from within. As reported in Caijing, Orienwise staff accused the company of fraudulent accounting, and claimed that the general manager of a subsidiary in Fujian province had exposed COG to 160 million yuan in failed loan guarantees [Caijing Staff, 2008]. Domestic banks started to pull their loan guarantees to COG, and international investors learned about the internal crisis 'through an anonymous letter from a former Orienwise executive who accused the company of financial malfeasance' [Zhang, Zhang, Chen and Fu, 2009]. COG's investors threatened to pull out. But Zhang Kaiyong persuaded them to retain their investments and conduct an audit while holding his 54 per cent stake in COG as collateral. An investigation committee comprising of the four international investors, PriceWaterhouseCoopers, and two law firms proposed taking over the operations of COG in the interim. Zhang objected. Four international board 
members resigned and investors filed a lawsuit against COG in Hong Kong, though Carlyle and Citigroup subsequently backed out [Epstein, 2009].

In speculative post-mortem accounts of COG's demise, observers point to red flags such as COG's registration in the Cayman Islands. At the time, however, even ADB's external legal counsel concurred that working with an offshore entity would be less bureaucratic than a PRC-listed company [Sharman, 2012]. Along similar lines, others reflect retrospectively, 'A diffuse holding structure that includes eight offshore and nine onshore entities makes it difficult to identify where assets may be hiding, or indeed, if the original structure still exists' [Robertson, 2014]. Ultimately, COG's failure was probably a combination of nontransparent governance, coupled with internal mismanagement and underregulation. Although COG's case attracted international media coverage, it was not alone. During the same period, Huading Guarantee Company was similarly exposed for poor risk management and irregular practices [Dong and Shan, 2010]. In 2012, the collapse of a particularly prominent CGC in Beijing, Zhongdan Investment Credit Guarantee, revealed that it had been advertising high returns to its customers by using portions of guaranteed loans to invest in wealth management products [Yang and Ma, 2012]. Similarly questionable practices were linked with waves of CGC failures in Wenzhou and Zhengzhou that same year.

\section{Gangyu Guaranty and Non-guaranty Affiliates}

The negative cases of CGCs discussed above receive more media attention than NBFCs that have well-functioning risk management systems in place, externally audited financial statements, and transparent corporate governance structures. Gangyu Guaranty and its affiliated NBFCs provide a more 
comprehensive, business-oriented counterpoint to the CGCs that are limited to a single financial service. In 2007, Gangyu was established in partnership with a Hong Kong-based investment group, Aktis Hanxi, in the western municipality of Chongqing [Atkis Hanxi Group, 2011]. ${ }^{16}$ As the first Sino-foreign CGC in Chongqing, Gangyu prides itself in using tighter credit scoring standards, conducting more in-depth due diligence of clients, and closer monitoring of staff and workflow processes than other CGCs. ${ }^{17}$ With extensive experience in foreign commercial and investment banks, Gangyu's board members and senior leadership have introduced a host of modern managerial practices, such as quarterly board meetings that include progress reports from various operations coordinators. In addition, unlike state banks and most CGCs, annual key performance indicators (KPIs) are set that incentivise middle managers to maintain high quality portfolios, while generating increasing revenues. Quarterly board meetings are followed up with on-site monitoring by the board chairman.

As one of the most stable and professional CGCs, Gangyu has built a vast network of working relationships with local banks and SMEs, and maintains a database with the credit history for hundreds of local businesses. At the end of 2013, Aktis increased its paid-in capital to 300 million yuan, giving it an 84.75 per cent stake. The additional capital infusion has facilitated Gangyu's expansion to a broader client base, including those with stronger credit profiles. In an industry marked by mismanagement and scandal, it is remarkable that as of mid2014, Gangyu had managed to maintain a credit default rate of 0.09 per cent since inception [Aktis Hanxi Group, 2014]. As CEO Feng Peisheng explains, 'Our core values are driven by building a sustainable base of high quality customers, not just maximizing revenues.' 
Through other Aktis-invested NBFCs, Gangyu is linked to a broader platform of credit guarantee, small loan, financial leasing, and fund management companies in Chongqing, Hubei, and Chengdu. Individually, none of them are as large in scale as ZKMFC or Credit Orienwise; taken together, they deploy 1.4 billion yuan of equity capital, enabling them to serve different financing needs of SMEs as they move through various cycles of development. For example, financial leasing is more practical for longer-term investments and expansion of production than a short-term loan from a small loan company. In other circumstances, going through a CGC to secure a medium-term loan from a bank may not be as convenient when a business faces urgent bridge financing for a few months. Given the fragmented nature of NBFC regulation and licensing in China, most NBFCs focus on developing clients for a single product, which facilitates economies of scale, but limits flexibility in adapting to client needs at varying stages of their business cycle. If well managed, as seen in Gangyu, a diversified network of licensed NBFCs provides a more comprehensive package of products, while diversifying risk exposure.

\section{NBFIs and Financial Development in Comparative Perspective}

The reliance of China's SMEs on NBFIs and less institutionalised forms of informal finance is understandable given the challenges they face in accessing bank credit. China's SMEs are not unique in this respect. According to the International Finance Corporation (IFC), SMEs in emerging markets account for 60 per cent of the global SME funding gap (total funding required minus total funding received), yet SMEs receive only 20 per cent of the total credit extended 
in the world [Sheng, $\mathrm{Ng}$ and Edelmann, 2013]. Within the latter, NBFIs represent the primary source of institutionalised credit for SMEs.

Traditional theories of development have tended to assume that NBFIs would gradually be displaced by banks — and that banks would be subsumed by financial markets-in a linear progression towards economic modernisation. Yet the post-war historical experience shows that the credit intermediation provided by NBFIs is not merely a transitional phenomenon in the process of financial development. NBFIs have played a more salient role in developing and newlyindustrialised economies, but they also represent a major source of SME finance even in countries with well-established banks and equity markets. There is a fundamental market logic to the enduring developmental and commercial relevance of NBFIs. As explained in a World Bank study [2002],

\begin{abstract}
NBFIs complement banks by providing services that are not well suited to banks; they fill the gaps in financial services that otherwise occur in bank-based financial systems. Equally important, NBFIs provide competition for banks in the provision of financial services. NBFIs unbundle the services provided by banks and provide the components on a competitive basis. They specialise in particular sectors and target particular groups. They overcome legal and tax impediments, and they enjoy informational advantages arising from specialisation. In addition to complementing banks, NBFIs can add to economic strength to the extent that they enhance the resilience of the financial system to economic shocks [Vlcek, 2014].
\end{abstract}

The positive functional roles of NBFIs are of course dependent on appropriate regulation and internal management of NBFIs themselves. Private NBFIs can be more nimble and innovative than policy-regulated banks and NBFIs subsidised by the government. With this in mind, the final section of this paper provides a brief historical overview of how SME financing evolved in Western Europe and North America, followed by more recent examples of non-banking financial intermediation in Asia. 
SME Finance in Early Industrialisers

Over the course of the late eighteenth to early twentieth centuries, modern financial institutions emerged in tandem with industrialisation in North America and various northern and west European countries. Most accounts of North Atlantic financial history focus on the rise of organised securities markets and universal banks in supporting military expenditures, infrastructure investment, long-distance trade, and industrial development [Dickson, P.G.M, 1967; Gerschenkron, 1962; Tilly, 1966 and Tracy, 1998]. Governmental entities and large enterprises were the primary beneficiaries of these formal financial institutions. As the industrialisation process facilitated the rise of large firms, it also fostered increasing heterogeneity in business organisation and scale. Vertically integrated corporations dominated the market for mass produced goods, while SMEs concentrated on niches requiring greater specialisation and flexibility. By the early twentieth century, all the leading industrial economies had flourishing SME sectors [Kinghorn and Nye, 1996].

Because equity markets and major banks were not geared towards low volume transactions, SMEs formed partnerships based on personal connections, and relied on alternative sources of finance, such as credit cooperatives, local banks, and informal intermediaries [Cull, Davis, Lamoreaux and Rosenthal, 2005]. A variety of practices based on localised networks emerged to support SME credit throughout the North Atlantic core. On the European continent, notaries accumulated information about borrowers and lenders in the process of drawing up contracts, which in turn, enabled them to broker assets. Notaries were less prevalent in Anglo-American countries, but the spread of credit reporting agencies supported the establishment of local banks to provide credit to SMEs. In 
France, short-term commercial debt took the form of trade credit. Diverse indigenous innovations for SME financing not only coexisted with increasingly sophisticated capital markets, commercial banks, and investment banks, but thrived due to growing demand [Cull et al., 2005].

The subsequent development of modern financial systems in the North Atlantic countries did not diminish the organisational diversity of financial institutions or the importance of NBFIs for SME financing. By the same token, bank-based financial systems have not been supplanted by capital market-based financial systems. Instead, financial intermediation chains have lengthened with the expanded role of NBFIs in mobilizing capital from non-financial sectors [Schmidt, Hackethal and Tyrell, 1999]. Growing functional specialisation of NBFIs reflects deepening market segmentation. As part of the demand-side of financial intermediation, NBFIs have retained their critical role in servicing the particular needs of SMEs that are neglected by equity markets and major banks.

\section{Non-Banking Financial Intermediation in Asia}

To the extent that historical insights may be extended from early North Atlantic industrialisers to contemporary Asian economies, it is apparent that NBFIs represent an enduring rather than transient phase of economic development. To be sure, the Asian financial crisis of the late 1990s led to bank restructuring and tighter regulation of NBFIs. A decade later, the global financial crisis also strained the real economy. But these shocks have not reduced the centrality of NBFIs for SME financing.

Korea's experience with NBFIs is instructive in this regard. During the 1980s, banks were privatised, and deregulation of the NBFI sector enabled Korea's industrial conglomerates, chaebols, to acquire controlling stakes over 
NBFIs. ${ }^{18}$ Over the course of the 1990s, NBFIs increasingly made loans to chaebol affiliates, which they financed by short-term borrowing at high interest rates. By 1997, NBFIs accounted for nearly half of all assets in Korea's financial system [Carmichael and Pomerleano, 2002]. The ensuing collapse in asset prices and bursting of the credit bubble motivated consolidation of the banking sector and restructuring of chaebols. ${ }^{19}$ In retrospect, it is evident that the combination of deregulation and weak financial supervision enabled conflict-of-interest in the corporate governance of NBFIs. NBFIs in Korea are now closely regulated and primarily serve SMEs rather than extensions of chaebols. ${ }^{20}$

As in other parts of East and Southeast Asia, NBFIs have played a key role in Malaysia's growth process [Islam and Osman, 2011]. Regarded by the World Bank [2015] as a 'highly open upper-middle income economy,' Malaysia is among thirteen countries in the world that has maintained growth rates exceeding 7 per cent for 25 years or more. Under the leadership of Prime Minister Mohathir Mohamad (1981 to 2003), Malaysia developed a diversified, industrialised economy with a bank-based financial system. The latter is complemented by non-banking financial intermediaries such as unit trusts, cooperative societies, leasing companies, and housing credit institutions. Even after the consolidation of financial institutions since 1997, assets held by Malaysia's NBFIs have grown in parallel with that of banks [Islam and Osman, 2011]. As in Korea, the NBFI sector has maintained a stable ratio of 47 per cent of the size of the banking system [Farid, 2013].

While the role of NBFIs in promoting growth in Asia's most dynamic economies is comparable to that of NBFIs in the North Atlantic core, the contemporary scale of non-banking financial intermediation in Asia is dwarfed 
by that of the US where NBFI assets exceed that of the banking system [IMF, 2014]. In the US, NBFIs are associated with the broader category of shadow banking, which includes investment banks, finance companies, money market funds, hedge funds, and special purposes vehicles/entities that aggregate and hold assets [Gao and Wang, 2010]. Shadow lending is also substantial in the UK and the Euro area, where it accounts for 360 and 180 per cent of GDP, respectively. For comparative reference, Figure 6 shows the global distribution of NBFI assets. The US, Euro area, and UK account for 79 per cent of NBFI assets, while China's shadow banking sector is only 4 per cent.

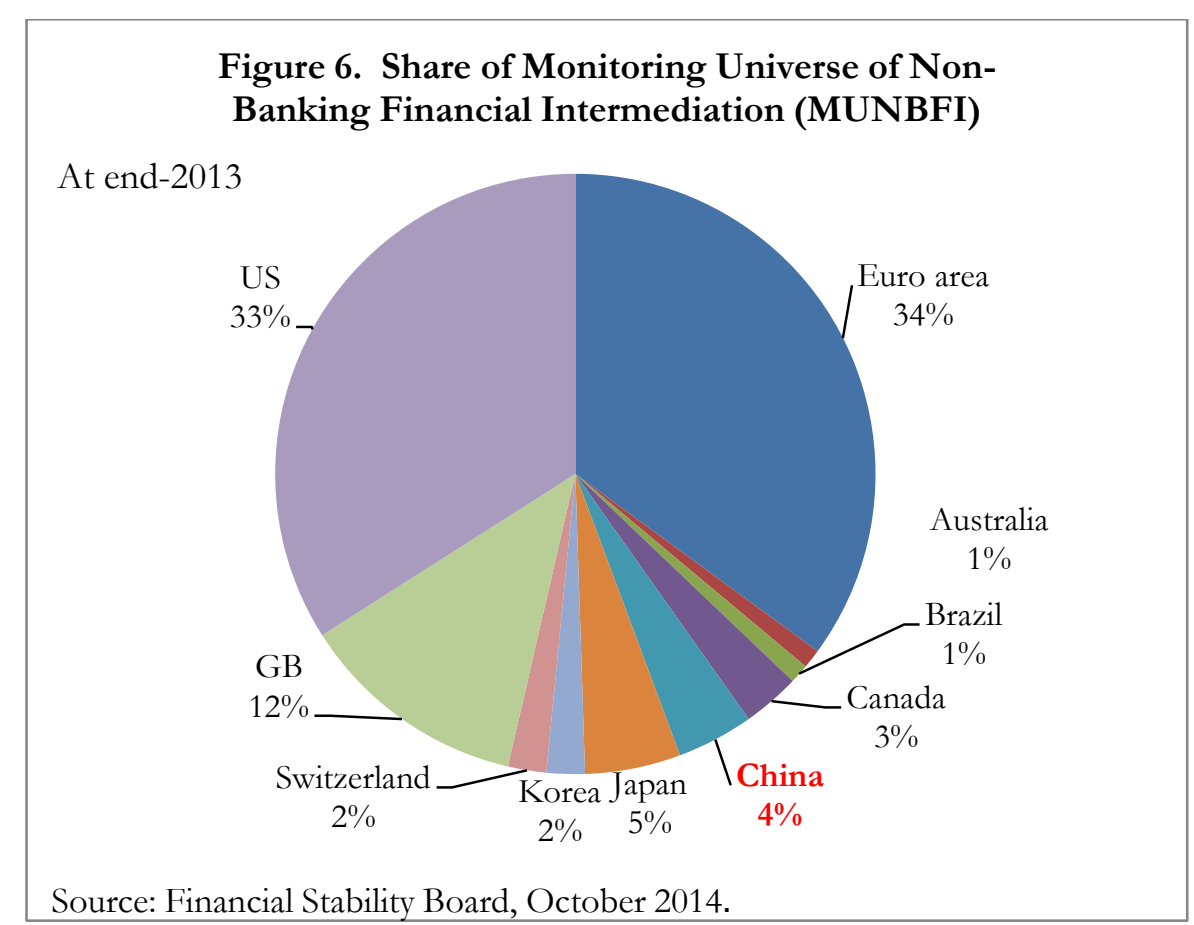

As discussed earlier, however, it is more meaningful to focus on the nature of risk posed by shadow banking rather than its aggregate volume. Returning to the three layers of shadow banking, prior to 2008, the bulk of shadow banking activity in the US occurred in the top 'bank off-balance sheet' layer, which poses the greatest degree of systemic risk. Although growth in 
shadow banking since 2009 has occurred mainly in 'traditionally less risky' areas,' the IMF finds that pension funds, insurance companies, and various money market, equity, bond, and hedge funds present the greatest marginal contribution to systemic risk (MCSR) in the US [Gao and Wang, 2010]. In the UK and Euro area, however, banks rather than NBFIs pose the greatest MCSR to their financial systems.

\section{Conclusion}

As in other parts of the world, China's SMEs face a financing gap that is structural in nature. Even though SMEs account for the overwhelming number of businesses, generate more employment than big businesses, and contribute meaningfully to GDP, traditional commercial banks are nonetheless biased towards larger-scale borrowers-even in highly liberalised financial systems. The near-universal bias against SME financing has an economic logic: it is less efficient to process numerous smaller loans; and due to limited credit history, collateral, and/or scale, SMEs carry a higher risk profile. With the exceptions of a handful of OECD countries, ${ }^{21}$ the SME funding gap has proven to be an enduring structural feature of both emerging and advanced market economies. This remains the case even in countries that have enacted a variety of policy measures to support SMEs and enhance financial inclusion more broadly.

In China, shadow banking represents a market response to a combination of policy restrictions and related political priorities. At the most basic level, financial repression allows SOEs to receive subsidised credit, while inhibiting the ability of banks to price loans for higher risk SMEs. As such, since the earliest years of reform, various types of informal financial intermediaries and NBFIs have emerged to fill the SME funding gap. Some lend directly to private 
businesses, while others guarantee loans from commercial banks. Meanwhile, artificial suppression of deposit rates has driven savers to seek higher returns from other investment opportunities. Banks thus turned to off-balance sheet products to generate earnings from alternative sectors. The recent rise of on-line P2P lending and crowd funding platforms bypasses the banking system altogether by brokering between SMEs and private lenders/investors. All of the above practices are regarded as shadow banking under the Financial Stability Board's expansive definition. But they present different types of risk, and in turn, invite different regulatory responses. The maturity transformation associated with off-balance sheet channeling poses the greatest systemic risk to the banking system. But even within this top bank off-balance sheet layer of shadow banking, China has not developed the volume or complexity of securitised products that triggered the global financial crisis. To avert such snowballing, since 2009 the CBRC has issued various notices requiring banks to disclose risks associated with WMPs, and ensure that WMPs are not linked with deposits [Hsu, 2014].

In the second, credit-enhancement layer of shadow banking, loans backed by CGCs expose banks to more traditional credit risk. Unlike complex derivatives, repackaged by multiple NBFIs, the risk from guaranteed bank loans stems from specific borrowers and should be known to the guarantor, if not the lender as well. However, as seen in the CGC case studies presented in the paper, considerable variation exists in the corporate governance, management, and sophistication of credit scoring systems employed by CGCs. This reflects in part the decentralised regulation of CGCs by local government entities. 
In the third non-bank lending layer, risk is concentrated to private lenders and borrowers, so client defaults in NBFIs such as microfinance/small loan companies pose little risk to social stability or the financial system. On the other hand, P2P platforms, and rotating savings associations mobilise individual savings without regulation or government safeguards, posing more of a risk to social stability than the banking system as a whole.

As in the second credit-enhancement layer, the non-banking layer of NBFIs encompasses a diverse range of entities. Some are unregistered, unlicensed, and limited to discrete local networks of lenders and borrowers. Such forms of informal finance avoid regulatory scrutiny as long as they are functional. At the other extreme are licensed NBFIs with transparent governance, and strong information management and credit systems. Some of these NBFIs have attracted foreign equity investment or listed publicly. A handful of CGCs, microfinance/small loan companies, and pawnshops fall into this subset of NBFIs. P2P and crowd funding have been operating in a regulatory void even while mobilizing millions of users. Given that internet financing platforms essentially mobilise deposits, they are likely to attract CBRC regulation in the near future.

China's regulators are actively cognizant of the relationship between financial repression and the modalities of risk posed by different forms of shadow banking. Although incremental liberalisation of interest rates on loans has occurred since the late 1990s, lifting the ceiling on deposit rates represents the most critical, and yet difficult, remaining step [Federal Reserve Bank of San Francisco, 2014]. (See Appendix C for a chronology of interest rate reform measures.) On the one hand, removing deposit rate ceilings would dampen 
demand for WMPs, which pose the greatest systemic risk. On the other hand, higher deposit rates would narrow the already shrinking profit margins of banks and SOEs, and could lead to greater interest rate volatility. Financial institutions and senior executives surveyed by DeLoitte and Touche in 2012 thus expect that full interest rate liberalisation will take another five to ten years [Federal Reserve Bank of San Francisco, 2014].

Interest rate liberalisation is unlikely to narrow the SME financing gap significantly, however. Besides the sheer volume of SMEs in China, the experience of other countries suggests that interest rate liberalisation does not translate into greater willingness of commercial banks to extend credit to SMEs. Traditional constraints on limited economies of scale, credit evaluation, loan monitoring, and collection are operational, rather than purely financial issues. Furthermore, SME promotion policies, such government-backed loan guarantee schemes, have not proven to be effective for supporting the most promising segment of SMEs.

In short, China's SME financing gap will persist. Despite official efforts at financial inclusion and interest rate liberalisation, NBFIs will remain the primary source of financing for China's SMEs. Even in advanced industrialised countries, NBFIs continue to serve critical segments of the economy due to the incentives of banks and securities markets to privilege larger-scale businesses. China's stateowned commercial banks and stock markets face similar incentives, but these are compounded by the political prioritisation of state firms in strategic sectors. Formal financial institutions in China are biased against SME clients for both economic and political reasons. By contrast, NBFIs are unencumbered by these dual constraints. Motivated by the glaring SME financing gap, a remarkable 
variety of NBFIs have flourished and floundered in China in the past three decades. Sensationalised accounts of shadow banking obscure the fact that an elite subset of credit guarantee, small loan, and financial leasing companies has developed locally grounded expertise in serving the particular needs of SMEs. Such NBFIs employ rigorous methods of financial accounting, credit scoring, and loan monitoring because they seek risk-adjusted returns on their investment. They are motivated by profit rather than politics.

Going forward, the policy challenge thus lies in establishing a regulatory framework for NBFIs that promotes best practices in a sector that has inspired both financial innovation as well as malfeasance. Fortunately, a modest core of well-managed, legally registered NBFIs provides a foundation for guiding future regulation. Within this core, foreign-invested and listed NBFIs are poised to provide a positive demonstration effect for corporate governance, credit evaluation techniques, and risk management. This is not to say that foreigninvested NBFIs are immune from scandal (e.g., Credit Orienwise). But such cases should be distinguished from legitimate NBFIs that are closely supervised by private stakeholders, both domestic and foreign, who are invested in building commercially successful NBFIs that serve SMEs.

Regulators have an opportunity to move such NBFIs out of the shadows. This sector is likely to grow and innovate rapidly and should be managed as a key source of SME funding. Reducing the opportunities for inter-bureaucratic and cross-jurisdictional regulatory arbitrage could be a guiding principle for a process that is bound to be complex. Multiple bureaucracies govern the spectrum of quasi-regulated NBFIs. The non-banking sector has this in common with other sectors in China's fragmented authoritarian political economy. 
However, social stability remains a leading concern for the regime, and financial stability is viewed as an essential component of that overarching goal. Given that China's present leadership has demonstrated willingness and capacity to centralise authority in priority areas, efforts to consolidate NBFI regulation are likely forthcoming as a component of China's on-going economic reforms and development.

\section{REFERENCES:}

Aktis Hanxi Group, December 30, 2011, 'Chongqing Gangyu Guaranty Co., Ltd.', available at: http://www.aktiscapital.com/html/news.php?id=39.

Aktis Hanxi Group, June 30, 2014, 'Guangyu Company Snapshot'.

All-China Federation of Industry and Commerce, various years since 1992, Private Economy Yearbook, Beijing: China Zhi Gong Press

Asian Development Bank, 2014, Asia SME Monitor 2013, Manila: Asia Development Bank.

Caijing Staff, December 26, 2008, 'Beijing Tried to Bail Out Credit Orienwise', Caijing.

Carmichael, Jeffrey and Michael Pomerleano, 2002, The Development and Regulation of Non-Bank Financial Institutions, Washington D.C.: The World Bank.

China Banking Regulatory Commission, 2014, China Banking Regulatory Commission 2014 Annual Report, part 4, cited in Gao, Simin and and Qianyu Wang, 2014, 'Chasing the Shadow in Different Worlds: Shadow Banking and Its Regulation in the U.S. and China', Manchester Journal of International Economic Law, Vol. 11, No. 3, pp. 440-41

CBRC, 2014, 'CBRC Vice Chairman Yan Qingmin Attended Small- and Micro-Sized Financial Service Sub-forum of Boao Forum for Asia'. Available at: http://www.cbrc.gov.cn/chinese/home/docView/C1B3D38F6C61440B024 B7FABEAD15A57.html

Cull, Robert, Lance E. Davis, Naomi R. Lamoreaux, Jean-Laurent Rosenthal, October 2005, 'Historical Financing of Small- and Medium-Sized Enterprises', NBER Working Paper Series, No. 11695, available at: http://www.nber.org/papers/w11695.pdf.

Dickson, P.G.M., 1967, The Financial Revolution in England: A Study in the Development of Public Credit, 1688-756 , London: St. Martin's Press.

Dickson, Bruce J., 2003, Red Capitalists in China: The Party, Private Entrepreneurs, and Prospects for Political Change, New York: Cambridge University Press.

Dong, Carolyn and Zhong Shan, June 2010, 'China's New Regulatory Framework of Financing Guarantee', China Bulletin, King \& Wood Mallesons, available at: http://www.kingandwood.com/article.aspx?id=China-s-New-RegulatoryFramework-of-Financing-Guarantee\&language=en\#\#1.

Epstein, Gady, March 6, 2009, 'Chinese Credit', Forbes. 
Epstein, Gady, March 26, 2009, 'Squeezed Middlemen', Forbes.

Farid, Muhamad Amar Mohd, 2013, 'Monitoring Shadow Banking and Its Challenges: The Malaysian Experience', Bank of International Settlements conference paper, pp. 6, Table 1, available at: http://www.bis.org/ifc/events/6ifcconf/mohdfarid.pdf

Federal Reserve Bank of San Francisco, May 2014, 'China's Interest Rate Liberalization Reform', Asia Focus, available at: http://www.frbsf.org/banking-supervision/publications/asiafocus/2014/may/china-interest-rate-liberalization-reform/Asia-FocusChina-Interest-Rate-Liberalization.pdf.

Financial Crisis Inquiry Commission, 2010, 'Preliminary Staff Report: Shadow Banking and the Financial Crisis', cited in Gao and Wang, 2010, 'Shadow Banking and its Regulation in the US and China', pp. 82-85 and pp. 432, nt. 71.

Financial Stability Board, 2013, Global Shadow Banking Monitoring Report, 14 November 2013, Basel: Financial Stability Board. Available at: http://www.financialstabilityboard.org/publications/r_131114.pdf.

Garaci, Michele, March 1, 2012, 'Fostering Development of SMEs', China Daily, available at:

http://usa.chinadaily.com.cn/opinion/2012-03/01/content_14726941.htm.

Gerschenkron, Alexander, 1962, Economic Backwardness in Historical Perspective, Cambridge, MA: Harvard University Press.

Hsu, Sara, May 2014, 'China's Regulation of Wealth Management Products', The Diplomat, available at: http://thediplomat.com/2014/05/chinas-regulationof-wealth-management-products/.

IMF, October 2014, 'Shadow Banking Around the Globe: How Large, and How Risky?' Global Financial Stability Report, Washington D.C.: International Monetary Fund. Available at:

https://www.imf.org/external/pubs/ft/gfsr/2014/02/pdf/c2.pdf.

Islam, Mohd Aminul and Jamil bin Osman, July 2011, 'Development Impact of Non-Bank Financial Intermediaries on Economic Growth in Malaysia: An Empirical Investigation,' International Journal of Business and Social Science Vol. 2, No. 14, pp. 187-98.

Jiang, Shuxia, 2009, 'The Evolution of Informal Finance in China and its Prospects', in Li, Jianjun and Hsu, Sara, (eds.), Informal Finance in China: American and Chinese Perspectives, New York: Oxford University Press.

Kinghorn, Janice Rye, John Vincent Nye, March 1996, 'The Scale of Production in Western Economic Development: A Comparison of Official Industry Statistics in the United States, Britain, France, and Germany, 1905-1913', Journal of Economic History, Vol. 56, pp. 90-112.

Kodres, Laura E., 2013, 'What Is Shadow Banking', Finance and Development, Vol 50, No. 2, available at: http://www.imf.org/external/pubs/ft/fandd/2013/06/pdf/basics.pdf.

Lardy, Nicholas R., 1998, China's Unfinished Economic Revolution, Washington D.C.: The Brookings Institution.

Li, Jianjun, 2009, 'Informal Finance, Underground Finance, Illegal Finance, and Economic Movement: A National Analysis', in Li, Jianjun and Hsu, Sara (eds.), Informal Finance in China: American and Chinese Perspectives (pp. 39-59), New York: Oxford University Press. 
Li, Jianjun and Fengyun $\mathrm{Hu}, 2013$, 'Zhongguo zhongxiao qiye jinrong jiegou, rongzi chengben yu xinzi xindai shichang fazhan [Financing structure and cost of China's small and medium-sized enterprises and development of the shadow credit market]', Hongguan jingji yanjiu[Macroeconomic research], Vol.5, pp. 7-11.

Macey, Jonathan, 2011-12, 'It's All Shadow Banking, Actually,' Review of Banking and Financial Law 31 (2011-2012), 593.

Netease Finance, 2014, 'DBS Chris Leung: It's Far from Enough to Only Adjust Stock Structure of SOEs', available at: http://money.163.com/14/0811/15/A3CI99HS00254TFQ.html

Nomura Global Markets Research, 2013, 'The Systemic Risk of China's Local Government Debt', Systemic Risk and Systemic Value, available at: http://systemicriskandsystematicvalue.blogspot.hk/2013/09/the-systemicrisk-of-chinas-local.html.

Pettis, Michael, 2013, Avoiding the Fall: China's Economic Restructuring, Washington D.C.: Carnegie Endowment for International Peace.

Pozar, Zoltan, Tobias Adrian, Adam Ashcraft and Hayley Boesky, 2010(Revised February 2012), 'Shadow Banking', Federal Reserve Bank of New York, Staff Report No. 458, New York: Federal Reserve Bank of New York, available at: http://www.newyorkfed.org/research/staff reports/sr458.pdf.

PRC National Audit Office, 2013, '2013 年第 24 号公告: 36 个地方政府本级政 府性债务审计结果[2013 Announcement No.24: Debt Audit Results of 36 Local Government]', available at: http://www.audit.gov.cn/n1992130/n1992150/n1992500/3291665.html.

PRC State Council, March 1, 2014, 'Document No. 107: Notice on Strengthening the Regulation of Shadow Banking', available at: http://www.hbxtsw.gov.cn/show news.asp?id=3558

Robertson, Benjamin, 2014, 'Credit Orienwise's Debt Default Lesson for Investors Buying into Mainland Bonds', South China Morning Post.

Schmidt, Reinhard H., Andreas Hackethal and Marcel Tyrell, 1999, 'Disintermediation and the Role of Banks in Europe: An International Comparison', Journal of Financial Intermediation, Vol. 8, pp. 36-67.

Sharman, J.C., 2012, 'Chinese Capital Flows and Offshore Financial Centers', The Pacific Review, Vol. 25, No. 2, pp. 331-32.

Sheng, Andrew, Chow Soon Ng and Christian Edelmann, 2013, Asia Finance 2020: Framing a New Asian Financial Architecture, Hong Kong: Oliver Wyman and Fung Global Institute Report.

Sheng, Andrew, Christian Edelmann, Cliff Sheng, and Jodie Hu, 2015, 'Bringing Light Upon the Shadow: A Review of the Chinese Shadow Banking Sector', Hong Kong: Oliver Wyman and Fung Global Institute Report.

Shi, Jianping, 2014, 'China MSME Finance Report 2014', Mintai Institute of Finance and Banking, Central University of Finance and Economics, pp. 23.

Situ, Peter, April 2011, 'Guarantee Funds for Inclusive Finance in China', China Papers on Inclusiveness, No. 3, pp. 11.

Solinger, Dorothy J., 1984, Chinese Business Under Socialism, Berkeley: University of California Press.

The World Bank Group, 2012, Enterprise Surveys, China, available at: http://www.enterprisesurveys.org/data/exploreeconomies/2012/china\#finan ce. 
The World Bank, 2015, 'Malaysia Overview', available at: http://www.worldbank.org/en/country/malaysia/overview.

Tilly, Richard, 1966, Financial Institutions and Industrialization in the Rhineland, 1815-1870, Madison: University of Wisconsin Press.

Tracy, James, 1998, A Financial Revolution in the Habsburg Netherlands, Berkeley: University of California Press.

Tsai, Kellee S., 2002, Back-Alley Banking: The Private Sector in Contemporary China, Ithaca, NY: Cornell University Press.

Tsai, Kellee S., 2007, Capitalism without Democracy: The Private Sector in Contemporary China, Ithaca, NY: Cornell University Press.

Vlcek, William, 2014, 'From Road Town to Shanghai: Situating the Caribbean in Global Capital Flows to China', British Journal of Politics and International Relations, Vol. 16, pp. 539-40.

Wang, Boli and Jianjun Li, 2013, 'Zhongguo yingzi yinhang de guimo, fengxian pinggu yu jianguan duice' [The size of Chinese shadow banking, risk assessment and supervision] Zhongyang caijing daxue xuebao [Central University of Finance and Economics Journal], Vol. 5, pp. 20-5.

Wang, Ling, January 05, 2015, 'Microfinance Play Seeks Macro Boost', The Standard Finance, available at: http://www.thestandard.com.hk/news detail.asp?we cat=16\&art id=15286 0 \&sid $=43633307 \&$ con type $=3 \& d$ str $=20150105 \& \mathrm{fc}=1$

Weinland, Don, September 29, 2014, 'P2P Lenders Await New Regulations from Beijing', South China Morning Post.

Weinland, Don, 2015, 'NPLs Overwhelm Chinese Lenders But State 'Bad Banks' Look the Other Way', South China Morning Post, available at: http://www.scmp.com/business/economy/article/1678398/nplsoverwhelm-chinese-lenders-state-bad-banks-look-other-way .

Wei, Lingling and Bob Davis, January 28, 2015, 'Debt That Once Boosted Its Cities Now Burdens China', Wall Street Journal. Available at: http://www.wsj.com/articles/debt-that-once-boosted-its-cities-nowburdens-china-1422415981.

Yang. Na and Yuan Ma, March 20, 2012, 'Fool's Gold Behind Beijing Loan Guarantees', Caixin.

Zhang, Bing, Man Zhang, Huiyin, Chen, Yanyan Fu, January 13, 2009, 'Ceasefire Buys Time for Credit Orienwise', Caijing.

Zhang, Moran, January 17, 2014, 'China's Wealth Management Products Lure Investors with Higher Yields', International Business Times.

Zhang, Yuzhe, Lin Tian, and Xiaoxiao Li, August 2012, 'Profits (and NPLs) Rise at Joint-Stock Banks', Caixin Online, available at: http://english.caixin.com/2012-08-30/100430982.html

Zhongguowang, 2012, 'Shao ning: 60\% of SOEs' Net Asset Have Already Entered Listed Enterprises'. Available at:

http://finance.china.com.cn/special/boao2012/20120402/633868.shtml

Zuoli Kechuang Micro-Finance Company Limited, Dec 30, 2014, Global Offering Prospectus, pp. 66 and 70. 
Appendix A. Official Definition of Businesses by Size and Industry in China

\begin{tabular}{|c|c|c|c|c|c|}
\hline Industries & Category & Big & Mid & Small & Micro \\
\hline $\begin{array}{l}\text { Agriculture, forestry, } \\
\text { fisheries; }\end{array}$ & Revenue & $>=200 \mathrm{mil}$ & $5 \mathrm{mil}$ to $200 \mathrm{mil}$ & $500 \mathrm{~K}-5 \mathrm{mil}$ & $<500 \mathrm{~K}$ \\
\hline \multirow[t]{2}{*}{ Industry } & Employees & $>=1,000$ & $300-1,000$ & $20-300$ & $<20$ \\
\hline & Revenue & $>=400 \mathrm{mil}$ & $20 \mathrm{mil}-400 \mathrm{mil}$ & $3 \mathrm{mil}-20 \mathrm{mil}$ & $<3 \mathrm{mil}$ \\
\hline \multirow[t]{2}{*}{ Construction } & Revenue & $>=800 \mathrm{mil}$ & $60 \mathrm{mil}-800 \mathrm{mil}$ & $3 \mathrm{mil}-60 \mathrm{mil}$ & $<3$ mil \\
\hline & Total Asset & $>=800 \mathrm{mil}$ & $50 \mathrm{mil}-800 \mathrm{mil}$ & $3 \mathrm{mil}-50 \mathrm{mil}$ & $<3 \mathrm{mil}$ \\
\hline \multirow[t]{2}{*}{ Wholesale } & Employees & $>=200$ & $20-200$ & $5-20$ & $<5$ \\
\hline & Revenue & $>=400 \mathrm{mil}$ & $50 \mathrm{mil}-400 \mathrm{mil}$ & $10 \mathrm{mil}-50 \mathrm{mil}$ & $<10 \mathrm{mil}$ \\
\hline \multirow[t]{2}{*}{ Retail } & Employees & $>=300$ & $50-300$ & $10-50$ & $<10$ \\
\hline & Revenue & $>=200 \mathrm{mil}$ & $5 \mathrm{mil}-200 \mathrm{mil}$ & $1 \mathrm{mil}-5 \mathrm{mil}$ & $<1 \mathrm{mil}$ \\
\hline \multirow[t]{2}{*}{ Transportation } & Employees & $>=1,000$ & $300-1,000$ & $20-300$ & $<20$ \\
\hline & Revenue & $>=300 \mathrm{mil}$ & $30 \mathrm{mil}-300 \mathrm{mil}$ & $2 \mathrm{mil}-30 \mathrm{mil}$ & $<2$ mil \\
\hline \multirow[t]{2}{*}{ Storage } & Employees & $>=200$ & $100-200$ & $20-100$ & $<20$ \\
\hline & Revenue & $>=300 \mathrm{mil}$ & $10 \mathrm{mil}-300 \mathrm{mil}$ & $1 \mathrm{mil}-10 \mathrm{mil}$ & $<1 \mathrm{mil}$ \\
\hline \multirow[t]{2}{*}{ Post } & Employees & $>=1,000$ & $300-1,000$ & $20-300$ & $<20$ \\
\hline & Revenue & $>=300 \mathrm{mil}$ & $20 \mathrm{mil}-300 \mathrm{mil}$ & $1 \mathrm{mil}-20 \mathrm{mil}$ & $<1 \mathrm{mil}$ \\
\hline \multirow{2}{*}{ Hotel\&Accomodation } & Employees & $>=300$ & $100-300$ & $10-100$ & $<10$ \\
\hline & Revenue & $>=100 \mathrm{mil}$ & $20 \mathrm{mil}-100 \mathrm{mil}$ & $1 \mathrm{mil}-20 \mathrm{mil}$ & $<1 \mathrm{mil}$ \\
\hline \multirow[t]{2}{*}{ Restaurant } & Employees & $>=300$ & $100-300$ & $10-100$ & $<10$ \\
\hline & Revenue & $>=100 \mathrm{mil}$ & $20 \mathrm{mil}-100 \mathrm{mil}$ & $1 \mathrm{mil}-20 \mathrm{mil}$ & $<1 \mathrm{mil}$ \\
\hline \multirow[t]{2}{*}{ Telecommunication } & Employees & $>=2,000$ & $100-2,000$ & $10-100$ & $<10$ \\
\hline & Revenue & $>=1$ bil & 10 mil -1 bil & $500 \mathrm{~K}-10 \mathrm{mil}$ & $<500 \mathrm{~K}$ \\
\hline \multirow[t]{2}{*}{ Soft and IT } & Employees & $>=300$ & $100-300$ & $10-100$ & $<10$ \\
\hline & Revenue & $>=100 \mathrm{mil}$ & $10 \mathrm{mil}-100 \mathrm{mil}$ & $500 \mathrm{~K}-10 \mathrm{mil}$ & $<500 \mathrm{~K}$ \\
\hline \multirow{2}{*}{$\begin{array}{l}\text { Real Estate } \\
\text { Development }\end{array}$} & Revenue & $>=2$ bil & 10 mil -2 bil & $1 \mathrm{mil}-10 \mathrm{mil}$ & $<1 \mathrm{mil}$ \\
\hline & Total Asset & $>=100 \mathrm{mil}$ & $50 \mathrm{mil}-100 \mathrm{mil}$ & $20 \mathrm{mil}-50 \mathrm{mil}$ & $<20 \mathrm{mil}$ \\
\hline \multirow[t]{2}{*}{ Property Management } & Employees & $>=1,000$ & $300-1,000$ & $100-300$ & $<100$ \\
\hline & Revenue & $>=50 \mathrm{mil}$ & $10 \mathrm{mil}-50 \mathrm{mil}$ & $5 \mathrm{mil}-10 \mathrm{mil}$ & $<5 \mathrm{mil}$ \\
\hline \multirow{2}{*}{$\begin{array}{l}\text { Lease and business } \\
\text { service }\end{array}$} & Employees & $>=300$ & $100-300$ & $10-100$ & $<10$ \\
\hline & Total Asset & $>=1.2$ bil & $80 \mathrm{mil}-1.2$ bil & $1 \mathrm{mil}-80 \mathrm{mil}$ & $<1 \mathrm{mil}$ \\
\hline Others & Employees & $>=300$ & $100-300$ & $10-100$ & $<10$ \\
\hline
\end{tabular}




\section{Appendix B: Overview of NBFI Regulations in China}

\section{Small Loan Company Regulations}

\begin{tabular}{|c|c|c|l|}
\hline Date & Regulation name & $\begin{array}{c}\text { Issuing } \\
\text { entity }\end{array}$ & \multicolumn{1}{c|}{ Main purpose } \\
\hline 2008 & $\begin{array}{c}\text { <Interim Measures for } \\
\text { Small Loan Companies> }\end{array}$ & CBRC1 1 & $\begin{array}{l}\text { Defines the nature of SLCs, specifies } \\
\text { conditions for establishing SLCs, SLC } \\
\text { financial sources and uses, as well as } \\
\text { their management and supervision. }\end{array}$ \\
\hline 2008 & $\begin{array}{c}\text { < Notice of Policies Related } \\
\text { to Rural Banking, Small } \\
\text { Loan and Mutually } \\
\text { Financial Cooperation> }\end{array}$ & CBRC & $\begin{array}{l}\text { Regulates statistical reporting, } \\
\text { supervision, and risk management of } \\
\text { rural banks, loan and small loan } \\
\text { companies, and mutual financing } \\
\text { cooperative organisations. }\end{array}$ \\
\hline 2014 & $\begin{array}{c}\text { Measures (exposure } \\
\text { draft)> }\end{array}$ & $\begin{array}{l}\text { CBRC, } \\
\text { PBOC2 } 2\end{array}$ & $\begin{array}{l}\text { that SLC's financing into banking } \\
\text { financial institution is a type of general } \\
\text { credit business, and requires SLC to } \\
\text { implement a supervision model similar } \\
\text { to banks. }\end{array}$ \\
\hline
\end{tabular}

\section{Loan Guaranty Regulations}

\begin{tabular}{|c|c|c|l|}
\hline Date & Regulation name & $\begin{array}{c}\text { Issuing } \\
\text { entity }\end{array}$ & \multicolumn{1}{c|}{ Main purpose } \\
\hline 2001 & $\begin{array}{c}\text { <Interim Measures for the } \\
\text { Risk Management of } \\
\text { Financing Guaranty } \\
\text { Agencies for SME }\end{array}$ & MOF $^{3}$ & $\begin{array}{l}\text { Clarifies the definition of 'financing } \\
\text { guaranty agencies for small and } \\
\text { medium-sized enterprises'; stipulates } \\
\text { their operation mode, business scope } \\
\text { and fund application; and promotes } \\
\text { the SMEs credit guaranty and re- } \\
\text { guaranty system in large scale. }\end{array}$ \\
\hline 2010 & $\begin{array}{c}\text { <Interim Regulation for the } \\
\text { Administration of Financial } \\
\text { Guaranty Institution }>\end{array}$ & CBRC & $\begin{array}{l}\text { Regulates the entry and exit, business } \\
\text { scope, operations, leverage, capital } \\
\text { usage, investment and risk } \\
\text { management of guaranty companies. }\end{array}$ \\
\hline
\end{tabular}


2. Loan Guaranty Regulations (continued)

\begin{tabular}{|c|c|c|c|}
\hline Date & Regulation name & $\begin{array}{l}\text { Issuing } \\
\text { entity }\end{array}$ & Main purpose \\
\hline 2011 & $\begin{array}{c}<\text { Notice of Stipulating the } \\
\text { Cooperation between } \\
\text { Banking and Guaranty } \\
\text { institutions }>\end{array}$ & CBRC & $\begin{array}{l}\text { Calls for long-term close cooperation } \\
\text { between banking and guaranty } \\
\text { institutions, especially in the areas of } \\
\text { SMEs and peasant households financial } \\
\text { services. Requires banking institutions } \\
\text { to optimise SMEs loans approval } \\
\text { procedures and implement the } \\
\text { corresponding interest preferential } \\
\text { policies. }\end{array}$ \\
\hline 2011 & $\begin{array}{l}<\text { Notice of Promoting the } \\
\text { Regulated Development of } \\
\text { Credit Guaranty Industry> }\end{array}$ & CBRC & $\begin{array}{l}\text { Calls on local governments at all levels } \\
\text { to perfect supporting policies, optimise } \\
\text { the external environment and } \\
\text { strengthen scientific supervision of } \\
\text { credit guaranty industry in order to } \\
\text { achieve its sustainable development. }\end{array}$ \\
\hline 2014 & $\begin{array}{c}<\text { Revised Regulation for the } \\
\text { Administration of Financial } \\
\text { Guaranty Institution } \\
\text { (Draft) }>\end{array}$ & CBRC & $\begin{array}{l}\text { Adds clarifications to existing rules } \\
\text { and calls for higher requirements for } \\
\text { the establishment, operation, and } \\
\text { expansion of financial guaranty } \\
\text { companies. }\end{array}$ \\
\hline
\end{tabular}

3. Financial Leasing Regulations

\begin{tabular}{|c|c|c|l|}
\hline Date & Regulation name & $\begin{array}{c}\text { Issuing } \\
\text { entity }\end{array}$ & \multicolumn{1}{|c|}{ Main purpose } \\
\hline $2005 / 2 / 3$ & $\begin{array}{c}<\text { Foreign Investment in the } \\
\text { Leasing Industry } \\
\text { Administration } \\
\text { Procedures }\end{array}$ & MOC $^{4}$ & $\begin{array}{l}\text { Specifies the administrative } \\
\text { department and administrative } \\
\text { regulations of foreign-invested } \\
\text { leasing companies. }\end{array}$ \\
\hline $2010 / 9 / 8$ & $\begin{array}{c}<\text { Notice about Tax Issues of } \\
\text { Assets Sale of Lessees in } \\
\text { Sales and Lease Back }\end{array}$ & SAT5 & $\begin{array}{l}\text { Specifies the tax issues of asset } \\
\text { sales of lessees and lease back. }\end{array}$ \\
\hline $2011 / 12 / 15$ & $\begin{array}{c}<\text { Guiding Policy about the } \\
\text { Promotion of Financial } \\
\text { Leasing in 12th Five Year } \\
\text { Plan> }\end{array}$ & MOC & $\begin{array}{l}\text { Promotes the financial leasing } \\
\text { industry in the 12th Five Year Plan. }\end{array}$ \\
\hline $2013 / 9 / 18$ & $\begin{array}{c}\text { Supeasures for the } \\
\text { Management of Financial } \\
\text { Leasing Companies> }\end{array}$ & MOC & $\begin{array}{l}\text { Specifies the supervision } \\
\text { department and management of } \\
\text { financial leasing companies. }\end{array}$ \\
\hline
\end{tabular}


3. Financial Leasing Regulations (continued)

\begin{tabular}{|c|c|c|c|}
\hline Date & Regulation name & $\begin{array}{c}\text { Issuing } \\
\text { entity }\end{array}$ & Main purpose \\
\hline 2013/12/10 & $\begin{array}{l}<\text { Interim Measures of } \\
\text { Commercial Banks } \\
\text { Factoring Management> }\end{array}$ & CBRC & $\begin{array}{l}\text { Specifies the regulated measures } \\
\text { of banks' factoring businesses. }\end{array}$ \\
\hline 20131212 & $\begin{array}{l}\text { No.106 document }<\text { Notice } \\
\text { of Incorporation Railway } \\
\text { Transport and Postal } \\
\text { Industry into VAT Pilot> }\end{array}$ & SAT & $\begin{array}{l}\text { Announces the incorporation of } \\
\text { the railway transport and postal } \\
\text { industries into the VAT pilot. }\end{array}$ \\
\hline $2013 / 12 / 15$ & $\begin{array}{l}<\text { Notice on Strengthening } \\
\text { the Shadow Banking } \\
\text { Supervision> }\end{array}$ & $\begin{array}{l}\text { State } \\
\text { Council }\end{array}$ & $\begin{array}{l}\text { Emphasises the importance of } \\
\text { non-banking credit } \\
\text { intermediation's regulation, risk } \\
\text { control and division of } \\
\text { responsibility. }\end{array}$ \\
\hline $2013 / 12 / 16$ & $\begin{array}{c}<\text { Financial Leasing } \\
\text { Company Administration } \\
\text { Measures }>\end{array}$ & CBRC & $\begin{array}{l}\text { Specifies the regulatory } \\
\text { management of financial leasing } \\
\text { companies. }\end{array}$ \\
\hline $2013 / 12 / 20$ & $\begin{array}{l}<\text { Policy on Speeding Up the } \\
\text { Development of Aircraft } \\
\text { Leasing Business }>\end{array}$ & $\begin{array}{l}\text { State } \\
\text { Council }\end{array}$ & $\begin{array}{l}\text { Establishes policies that support } \\
\text { aircraft leasing businesses to } \\
\text { promote the development of the } \\
\text { aircraft industry in China. }\end{array}$ \\
\hline $2014 / 3 / 1$ & $\begin{array}{c}<\text { Interpretation on the } \\
\text { Applicable Law of the } \\
\text { Financial Leasing Contract } \\
\text { Dispute Cases }>\end{array}$ & $\mathrm{SPC}^{6}$ & $\begin{array}{l}\text { Explains disputed legal problems } \\
\text { in financial leasing businesses. }\end{array}$ \\
\hline
\end{tabular}

Note:

1. CBRC: China Banking Regulatory Commission.

2. PBOC: People's Bank of China.

3. MOF: Ministry of Finance.

4. MOC: Ministry of Commerce.

5. SAT: State Administration of Taxation.

6. SPC: The Super People's Court. 
Appendix C: Timeline of China's Interest Rate Liberalisation Reform

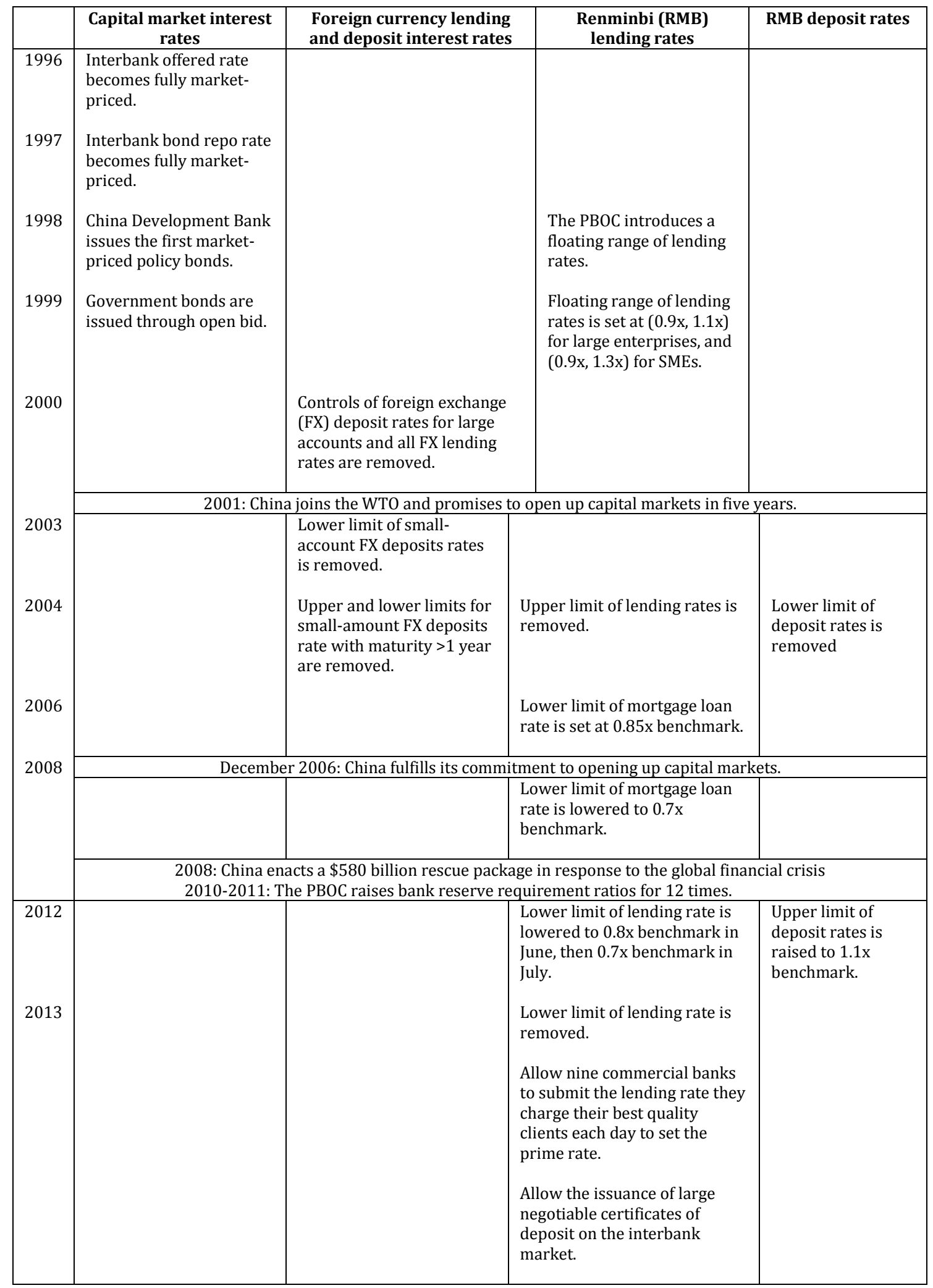

Source: Federal Reserve Bank of San Francisco, 'China's Interest Rate Liberalization Reform’ (May 2014). 
${ }^{1}$ China's official definition of SMEs has shifted over the course of the reform era, and also varies by industry. Appendix A delineates the various official definitions of SMEs by sector.

${ }^{2}$ There was an ideological rationale for this restriction on the number of employees that private firms could hire. According to Karl Marx's Das Kapital, household producers with less than eight workers are considered 'non-exploitative,' while those with more than eight employees are 'exploitative capitalist producers.'

${ }^{3}$ The following section draws in part from [author self-reference deleted].

${ }^{4}$ In practice, banks have managed to evade interest rate ceilings on loans by requiring borrowers to re-deposit half of the loan with the lending bank, but such practices obfuscate transparency in loan documentation.

${ }^{5}$ Of course informal finance in China not only pre-dates the reform era, but has been traced back to emergence of the private lending contract in the Xi-Zhou Dynasty (1046 BC). For a brief overview, see Jiang (2009).

${ }^{6}$ There are two main opportunities for financial arbitrage. First, because bank deposit rates are artificially repressed, there is market demand for higher-yielding investment products offered through banks. Second, because banks face very high reserve requirements as well as sectorbased restrictions on lending activity, they move their lending off-balance sheet by investing in assets that would ordinarily be financed through bank credit.

${ }^{7}$ As Macey (2011-2012) puts it, the term shadow baking implies that 'it must be nefarious, somewhat clandestine and of dubious legality.'

${ }^{8}$ The Financial Stability Board was established in 2009 as a successor to the Financial Stability Forum.

${ }^{9}$ The reason for distinguishing 'legitimately registered' entities from those with any form of registration is because some non-banking financial institutions disguise themselves as other types of businesses to avoid regulatory attention.

${ }^{10}$ In January 2014 alone, 121 new P2P platforms were established, while 69 either went bankrupt or became insolvent when investors tried to withdraw their funds prior to the lunar new year. As of February 2015, there were 1,627 on-line lending platforms tracked by Wangdaizhijia.com. '69 Troubled P2P Lending Platforms Reported in China in January,' Shanghai Daily, February 3, 2015, available at: http://www.shanghaidaily.com/business/69-troubled-P2Plending-platforms-reported-in-China-in-Jan/shdaily.shtml.

11 This is higher than official estimates, which report total government debt of less than 23 per cent of GDP in 2014: Ministry of Finance, cited in 'China Government Debt to GDP', tradingeconomics, available at http://www.tradingeconomics.com/china/government-debt-togdp.

${ }^{12}$ According to the CBRC, assets held by trusts have grown from less than RMB1 trillion in 2007 to RMB 9.08 trillion by June 2014 .

${ }^{13}$ Due to limited state investment and arable land, the local government quietly permitted petty commerce and household factories even before the official commencement of economic reform.

${ }^{14}$ As of February 2015, the application for a license to operate beyond Deqing remained pending.

15 On its first day of trading, ZKMFC's share price was up by 42 per cent: the listing price was $\$ 1.30 /$ share and the closing price at day end was $\$ 1.85 /$ share. 
${ }^{16}$ Aktis Hanxi is 'a partnership of experienced former banking and investment professionals who have conducted direct investment activities together in the developing and emerging market economies of the Asia region since 2003'.

17 This section is based on the author's interviews with Aktis partners, and Board members and senior management of Gangyu in December 2014 and March 2015, respectively.

18 'By 1997, the 70 largest chaebols owned a total of 114 financial affiliates, mostly merchant banks, securities companies, non-life insurance companies, and installment credit companies.' Joon-Kyung Kim and Yung Chul Park, October 24, 2011, 'Financial Liberalization and Regulatory Changes in Korea,' KDI School and Korea University, pp. 7.

${ }^{19}$ In 1998, 13 out of the 27 commercial banks in Korea were closed down.

${ }^{20}$ Studies of NBFI lending patterns in Korea before and after the 1997 financial crisis show that the total factor productivity of SMEs receiving loans following the crisis became significantly higher than that of the larger firms receiving credit from NBFIs before 1997. Jungsoo Park and Yung Chul Park, May 2014, 'Has Financial Liberalization Improved Economic Efficiency in the Republic of Korea? Evidence from Firm-Level and Industry-Level Data', ADBI Working Paper Series, No. 480, available at:

http://www.adbi.org/files/2014.05.14.wp480.financial.liberalization.korea.pdf.

21 Within the OECD, as of 2012, SMEs received the highest percentage of bank loans in Sweden (91\% in 2011), Switzerland (78.8\%) Portugal (74.7\%), Korea (74.7\%), Ireland (67.5\%), and Belgium (65.1\%). OECD, Financing SMEs and Entrepreneurs 2014, p. 35, Table 1.3, available at: http://www.keepeek.com/Digital-Asset-Management/oecd/industry-and-services/financingsmes-and-entrepreneurs-2014 fin sme ent-2014-en\#page37. 